\title{
NUTRIENT UPTAKE IN TETRAHYMENA PYRIFORMIS
}

\author{
by
}

\author{
LEIF RASMUSSEN
}

The Biological Institute of the Carlsberg Foundation

16 Tagensvej, DK-2200 Copenhagen N, Denmark

Key words: food vacuoles; pinocytic vesicles; plasma membrane

\begin{abstract}
Several morphological structures have been implicated in nutrient uptake in the ciliate protozoon, Tetrahymena pyriformis: food vacuoles, various types of vesicles and the plasma membrane. It is the object of this report to discuss the roles of these organelles in food uptake. Measurements of multiplication rates under conditions where food vacuole formation could be controlled experimentally suggested that the food vacuoles (about $5 \mu \mathrm{m}$ in diameter) were essential for rapid cell multiplication in various standard growth media. If, however, concentrations of certain specific nutrients (different for different strains of $T$. pyriformis) were high, then the cells could multiply rapidly even when food vacuoles were absent. Furthermore, multiplication rates of cells supplied with particulate or dissolved egg albumin as the amino acid source, suggested that the food vacuoles took up particulate egg albumin well, but dissolved egg albumin poorly. The role in food uptake of vesicles with a diameter of less than $1 \mu \mathrm{m}$ remains largely unknown. Our present knowledge of them is not yet sufficiently detailed to permit estimations of the rates with which they are formed or of their total number per cell. The plasma membrane has carrier-mediated uptake sites for a number of nutrients such as amino acids and nucleosides. It is likely that this type of uptake mechanism plays a quantitatively important role in $T$. pyriformis whenever such compounds are present in the extracellular fluid.
\end{abstract}




\section{CONTENTS}

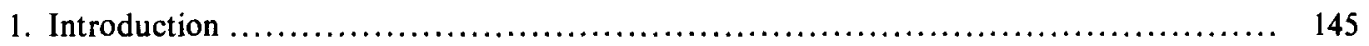

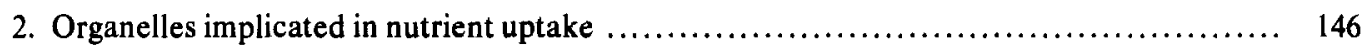

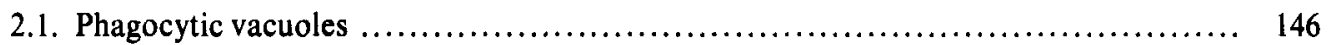

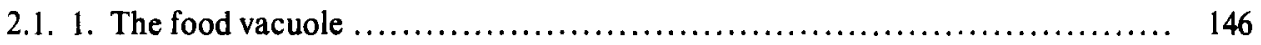

2.1. 2. Induction of food vacuoles....................................... 148

2.1. 3. Rates of food vacuole formation ................................... 148

2.1. 4. Food vacuoles and lysosomes ................................... 149

2.1. 5. Egestion of food vacuoles ......................................... 150

2.1. 6. Efficiency of particle collection .................................. 150

2.1. 7. Total volume of food vacuoles formed in a generation time ................ 150

2.1. 8. Area of food vacuole membranes .................................... 151

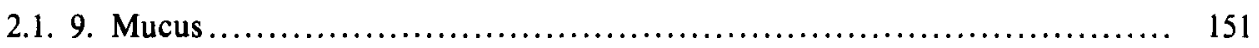

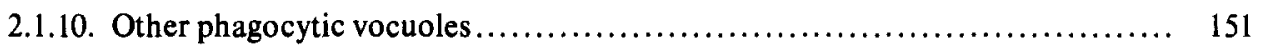

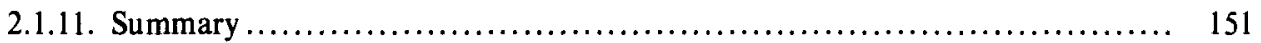

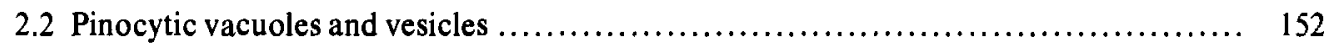

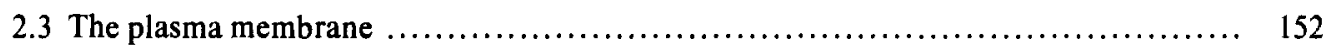

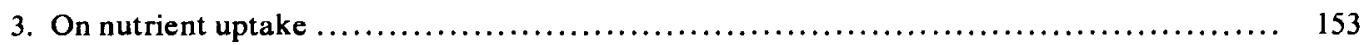

3.1 Nutrient uptake by membrane invaginations ............................... 153

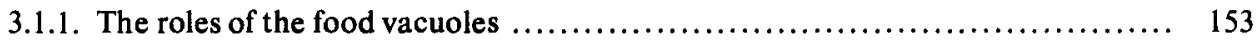

3.1.1.1. Cell multiplication and reduced food vacuole formation .............. 153

3.1.1.2. Cell multiplication and particulate material ....................... 155

3.1.1.3. On the role of the food vacuole .............................. 156

3.1.1.4. Food vacuole volumes and nutrient uptake ..................... 157

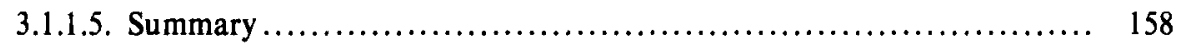

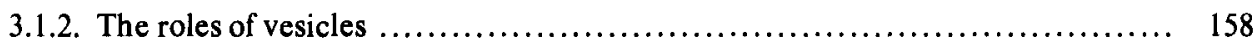

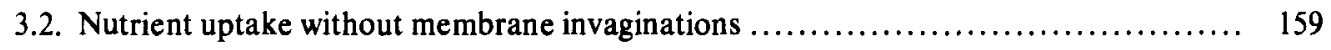

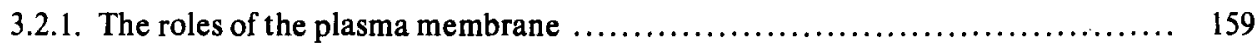

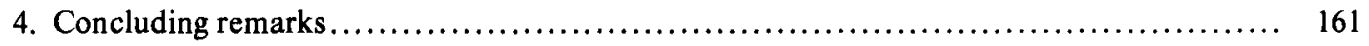

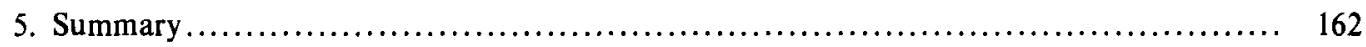

6. References............................................................ 164 


\section{INTRODUCTION}

How do ciliates take up their nutrients? It is generally accepted that free-living ciliates digest particulate food in their food vacuoles prior to uptake and that parasitic, astomatous ciliates do not form food vacuoles: they take nutrients up through the entire body surface (see e.g. ref. 36). It is also accepted that these astomatous forms have developed from free-living forms (36). This gives rise to the question if free-living ciliates can feed in rich nutrient media in the absence of food vacuoles. This and other problems on nutrient uptake will be discussed for a free-living ciliate, Tetrahymena pyriformis (Fig. 1).

It was proposed long ago that $T$. pyriformis could take up all nutrients in the absence of food vacuoles. Thus LWOFF (55) reported in 1923 that ciliates, identified as $T$. pyriformis (56) grew and multiplied in sterile solutions of peptone without having food vacuoles. He proposed that food uptake in $T$. pyriformis could occur by an "ectoplasmic route". This proposition appears to have been forgotten, but the fact remains that experimental evidence for a dual capacity for nutrient uptake in $T$. pyriformis was presented more than 50 years ago.

Few investigators have compared the contribution of the food vacuoles to total nutrient uptake of $T$. pyriformis (LWOFF (55), SEAMAN (98, 99), Pruett, Conner \& Pruett (77), Nilsson (63), RASMUSSEN $(79,80)$, RASMUSSEN \& ORIas $(84,85)$ and ORIaS \& RASMUSSEN $(71,72))$. There are, therefore, no reasonably detailed descriptions of nutrient uptake for this cell. Such descriptions should include accounts of the roles of food vacuoles, other vesicles and cell surface in the uptake processes. Ultimately, the relative contributions of these organelles in cell nutrition must be established for a variety of culture conditions.

Recent findings provide a foundation to evaluate the roles of some of the organelles participating in nutrient uptake in T. pyriformis. They (a) confirm LWOFF's proposal that the cells can grow and multiply without food vacuoles; (b) demonstrate that particulate, but not dissolved, egg albumin can provide amino

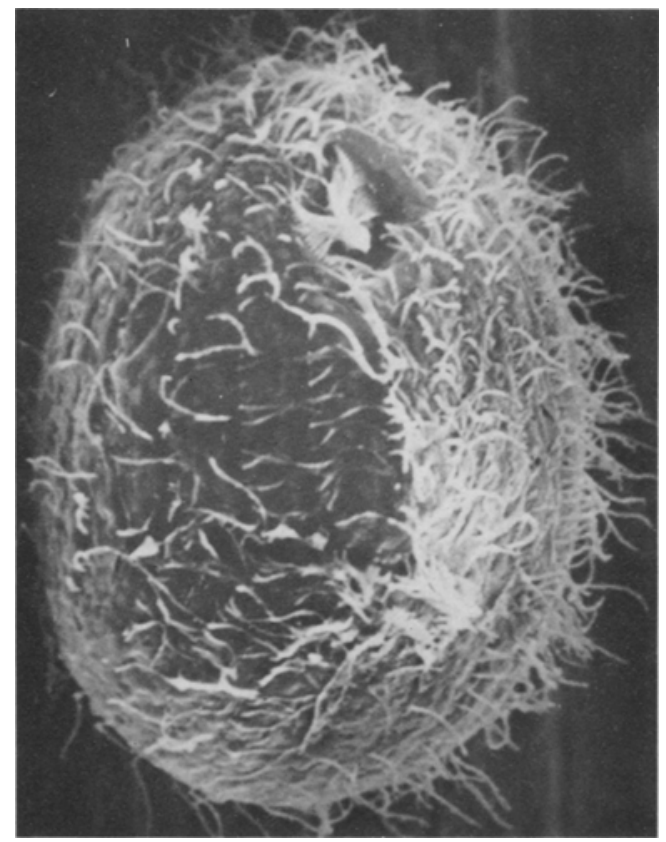

Figure 1. Tetrahymena pyriformis. Scanning electron micrograph. The length of the cell is about $50 \mu \mathrm{m}$. Reproduced by courtesy of Dr. H. E. Buhse, Jr.

acids for rapid cell multiplication; (c) include evidence for mediation of transport sites, "pumps", in the uptake of amino acids, carbohydrates and nucleosides in T. pyriformis. These results allow us to see under which environmental conditions food vacuoles are essential, stimulatory or inadequate for nutrient uptake required for continued growth and cell multiplication. The results permit the suggestion that the major part of the required nutrients when present in their free, unpolymerized form can permeate the cell surface fast enough to support rapid cell multiplication in rich media.

Recently, the literature on $T$. pyriformis has been reviewed in two books, one authored by HILL (40) and the other edited by ELLIOTT (27). CONNER (17) summarized our knowledge of nutrient uptake in protozoa, and HoLz (48) and DUNHAM\& KROPP (24) surveyed nutrient uptake in $T$. pyriformis. HUTNER, BAKER, FRANK $\& \operatorname{Cox}(51)$ made a review of the field of nutrition in protozoa. 


\section{ORGANELLES IMPLICATED IN NUTRIENT UPTAKE}

Nutrient uptake in $T$. pyriformis is mediated by vacuoles, vesicles and the plasma membrane. The first of these include phagocytic vacuoles (food vacuoles, and possibly others) containing particles visible in the light microscope (particles larger than $0.2 \mu \mathrm{m}$ ) and the second pinocytic vesicles containing no such particles. All contain some of the fluid in which the cells are suspended. There is a tendency to use the collective term, endocytosis, for uptake involving vacuoles and vesicles.

\subsection{Phagocytic Vacuoles}

Phagocytic vacuoles play an important role in food uptake. Each time a vacuole is formed

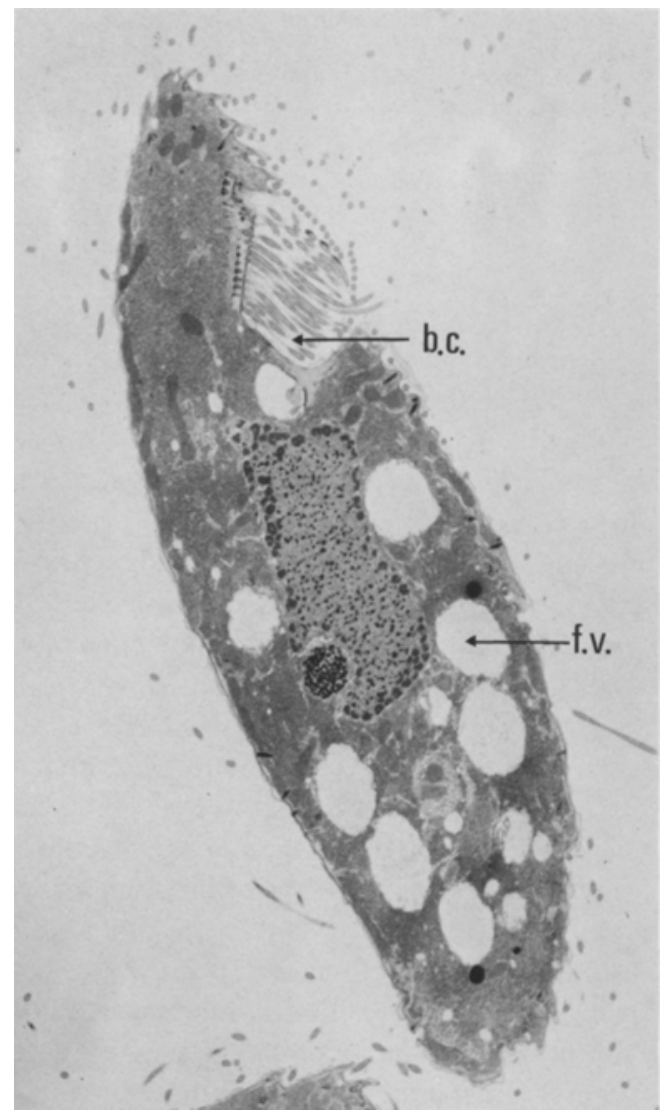

Figure 2. Mid-longitudinal section of Tetrahymena pyriformis. Abbreviations: b. c.: buccal cavity; f. v.: food vacuole. Reproduced by courtesy of Drs. I. L. Cameron and D. L. Hill and Academic Press from ref. 40 . nutrients are internalized: these may include food particles, compounds dissolved in the fluid surrounding the particles, and possibly mucous material with adsorbed molecules as proposed by NILSSON (63). Digestion then takes place in the vacuole and digestion products penetrate the food vacuole membrane on their way to the cytoplasm of the cell.

Phagocytic vacuoles of the type known as food vacuoles (Fig. 2) are produced by the oral apparatus. The beating of the three oral membranelles and the undulating membrane (FURGASON (34)) maintains a current of extracellular fluid and suspended particles through the buccal cavity. Food particles and their surrounding medium fill up the receiving vacuole (CORLISS (18)), which is pinched off to form a food vacuole. The oral apparatus has been isolated in mass and subjected to microscopic and biochemical studies (WILLIAMS \& ZEUTHEN (115), Forer, NiLSSON \& ZEUTHEN (30), ElliotT \& KENNEDY (29), Williams, Michelsen \& ZeUTHEN (113), Wolfe (117), RaNNESTAD \& Williams (78), Williams \& NELSON (114), and Gavin (35)).

\subsubsection{The food vacuole}

When viewed under the phase contrast microscope food vacuoles usually appear as spherical bodies. They become clearly visible in the normal light microscope after addition of particulate material to the medium, for example bacteria (ELLIOTT \& Clemmons (28) and RICKETTS (90)), India ink particles - Fig. 3 (Elliott \& Clemmons (28) and Orias \& POLlOCK (70)), carmine particles (CHAPMANANDRESEN \& NILSSON (13) and NILSSON (63)), yeast cells and latex particles (RICKETTS (90)), dimethylbenzanthracene particles (ROTHSTEIN \& BLUM (93)) and heat-coagulated egg albumin particles (RASMUSSEN, unpublished observations).

ChAPMAN-ANDRESEN \& NiLSSON (13) reported an average of 30 food vacuoles per cell in a population growing exponentially in the standard medium of 2 per cent proteose peptone, liver extract and salts (PLeSNer, RASMUSSEN \& ZEUTHEN (76)). RASMUSSEN \& KLUDT (82) found 26 vacuoles per cell in autoclaved 2 per cent proteose peptone broth. 


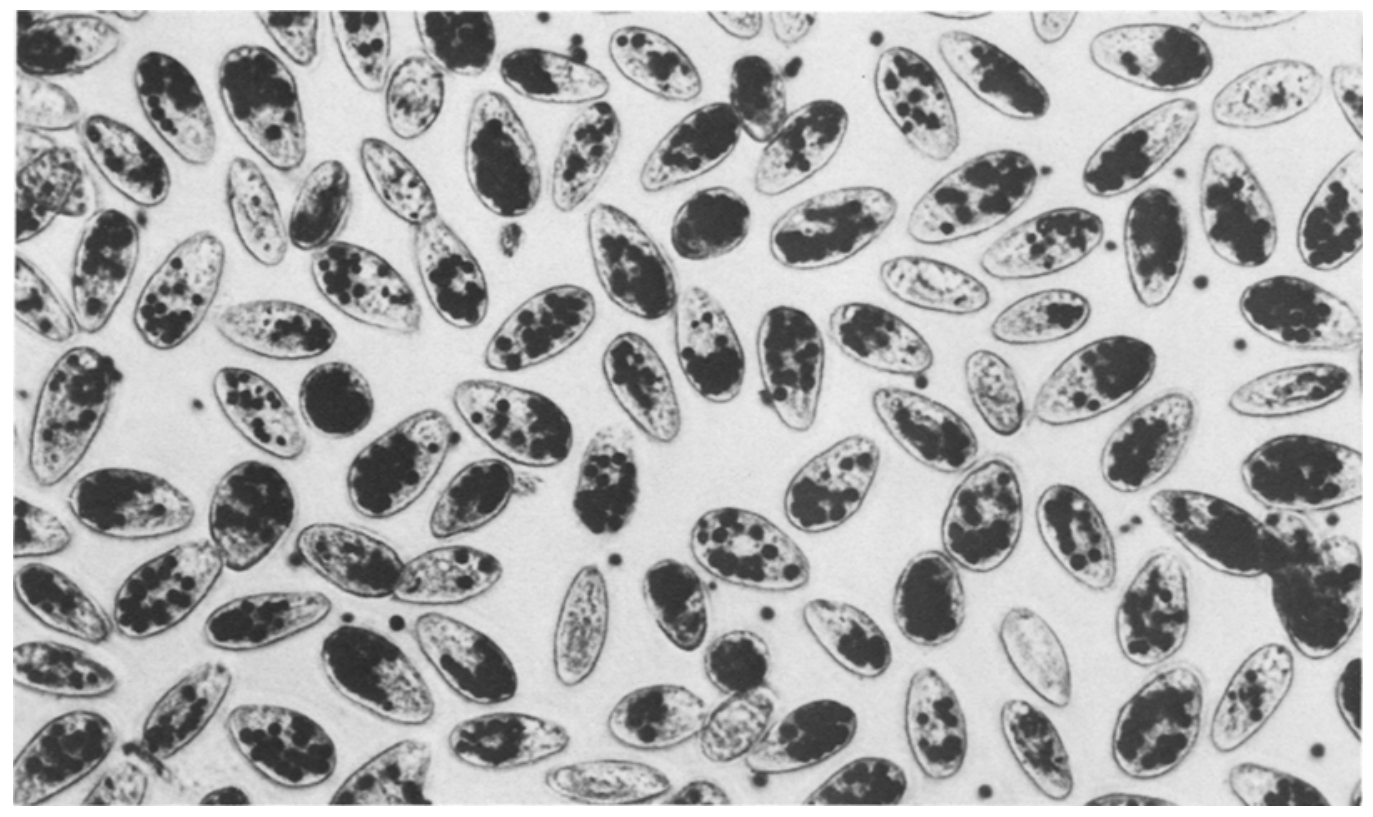

Figure 3. Food vacuoles in Tetrahymena pyriformis, syngen 1, DIII, labelled with India ink particles. A $10 \mathrm{ml}$ cell suspension was incubated for 30 minutes with $1 \mathrm{ml}$ of a 0.1 per cent ink suspension and fixed. The India ink was obtained from "Rotring 4 , W. Germany, and it was used throughout this study.

LYKKESFELDT (personal communication) and RASMUSSEN \& KLUDT (unpublished observations) found 15 and 17 food vacuoles per cell, respectively, in cells growing exponentially in the chemically defined medium of HOLZ, ERWIN, ROSENBAUM \& AARONSON (49).

The average diameter of newly-formed vacuoles in cells from good nutrient media is 5 $\mu \mathrm{m}$ (ChAPMAN-ANDRESEN \& NilsSON (13) and NILSSON(63)) or $6 \mu \mathrm{m}$ (RASMUSSEN, BUHSE \& GROH (81)). RICKETTS (90) recorded average diameters up to $7.3 \mu \mathrm{m}$. No values are available for the lower limit of newly-formed vacuoles. Food vacuoles decrease in size after their formation: CHAPMAN-ANDRESEN \& NILSSON (13) found that "old" food vacuoles had an average diameter of $2 \mu \mathrm{m}$ in starving cells.

In the experiments to be described in section 3 the presence or absence of food vacuoles in $T$. pyriformis was established by phase contrast and ordinary light microscopy, at magnifications of $40 \times 12$ times (RASMUSSEN \& KLUDT (82), RASMUSSEN (79), RASMUSSEN \& ORIAS $(84,85)$ and ORIAS \& RASMUSSEN $(71$,
72)). The cells were incubated with India ink particles for 30 minutes or more and then fixed (Fig. 3). Microscopy of the cells revealed vacuoles with diameters conservatively estimated to exceed $1 \mu \mathrm{m}$ (NILSSON, personal communication; ORIAS \& RASMUSSEN (72)). This method therefore disclosed only relatively large phagocytic vacuoles, among these the food vacuoles; vesicles with diameters below 1 $\mu \mathrm{m}$ may have passed undetected.

Material enclosed in food vacuoles is surrounded by a unit membrane (ELLIOTT \& Clemmons (28) and NilsSON \& Williams (67)). WEIDENBACH \& ThOMPSON (109) studied phospholipid composition in different sub-cellular fractions of starving $T$. pyriformis. They found that the vacuolar distribution of phospholipids resembled most closely that of the microsome fraction and proposed that the former might arise from the latter. This conclusion was supported by measurements of radioactivity of $\mathrm{P}^{32}$-phosphate in sub-cellular fractions: after induction of food vacuoles for 10 minutes by addition of ferric oxide particles to starving cells, the activity was lower in the 
food-vacuolar fraction than in any other fraction. The authors suggested on basis of these results that the lipid components of the food vacuoles were not made de novo at the time of the food vacuole formation. They also found that the cells formed as many as four vacuoles in the absence of protein synthesis and took this as evidence that there was an intra-cellular store of vacuolar membrane proteins. In agreement with this interpretation of the biochemical studies ALLEN's (2) electron microscopical investigations suggested a re-cycling of food vacuole membranes in Paramecium caudatum (section 2.1.5).

If the food-vacuolar membranes arise from the microsome fraction in $T$. pyriformis this points to a difference between this and other cells: UlSAMER, SMITH \& KORN (106) and UlSAMER, WRIGHT, WETZEL \& KORN (107) working with amoebae and Stossel, MASON \& VAUGHaN (103) working with leukocytes proposed that vacuolar membranes in these cells arose from surface membranes.

\subsubsection{Induction of food vacuoles}

Formation of food vacuoles can be induced by particulate material. The process was induced by digestible particles: bacteria (RICKETTS (90)), bits of spleen tissue (MULLER \& ROHLICH (61)) and heat-coagulated egg albumin (RASMUSSEN \& Modeweg-Hansen (83)). Formation of food vacuoles was also induced by non-digestible particles: latex granules (MULLER \& ROHLICH (61)), carmine particles (CHAPMAN-ANDRESEN \& Nilsson (13)), polystyrene particles (RASmussen \& Modeweg-Hansen (83)) and India ink particles (RASMUSSEN, unpublished observations). NILSSON (63) stated that very few particles may be needed to initiate food vacuole formation.

It is an open question if compounds in solution can induce formation of food vacuoles. RASMUSSEN \& KLUDT (82) observed as few as 34 vacuoles per cell in a filter-sterilized, "particle-free" 2 per cent proteose peptone medium. RASMUSSEN (79) found under certain strict conditions an average value of less than 1 vacuole per cell. No food vacuoles were formed in single live cells under these conditions (see section 3.1.1.1.). ChapMAN-ANDRESEN \&
NiLsSon (13) found that no food vacuoles were formed in cells suspended in starvation medium, unless inert particles such as carmine were added as a stimulant. NiLSson (63) later reported that glucose and radioactive thymidine and uridine induced formation of some vacuoles, but the addition of particles does not seem to have been excluded. It is very difficult to establish if particles are necessary to induce vacuole formation. In fact it may be questioned whether reliable methods exist to permit measurements of rates of formation of food vacuoles in populations of $T$. pyriformis. The methods used depend on adding foreign particles in numbers which nearly always cause a large increase in the concentration of particles in the cell suspension. The conditions under which each experiment is made should be stated: conclusions are only valid for specific situations.

\subsubsection{Rates of food vacuole formation}

The frequency with which food vacuoles are formed has been studied under many conditions. ChapMAN-ANDRESEN \& NiLSSON (13) found that the frequency varied with the position of the cell in the cell cycle: no food vacuoles were formed for about 20 minutes prior to cell division. NILSSON (63) reported that changes in external factors such as temperature, acidity and composition of the ionic environment inhibited vacuole formation. Using carmine particles to label new food vacuoles, she found that $T$. pyriformis, GL, suspended in 2 per cent proteose peptone with liver extract and salts, formed an average of about three vacuoles per 10 minutes at $28^{\circ} \mathrm{C}$. Similarly, using India ink particles to label new food vacuoles, HoFFMANN, RASMUSSEN \& ZEUTHEN (43) found that cells in media of the same type formed from 7.2 to 9.2 vacuoles in 25 minute periods, and LYKKESFELDT (personal communication) obtained an average of 10 food vacuoles per 30 minutes in a chemically defined medium. These values all indicate a formation rate of about 1 vacuole per 3 minutes. However, carmine and India ink particles do not give the same results over longer incubation periods. NiLSSON (63) reported about 3 food vacuoles per average cell after 10 to 15 minutes 


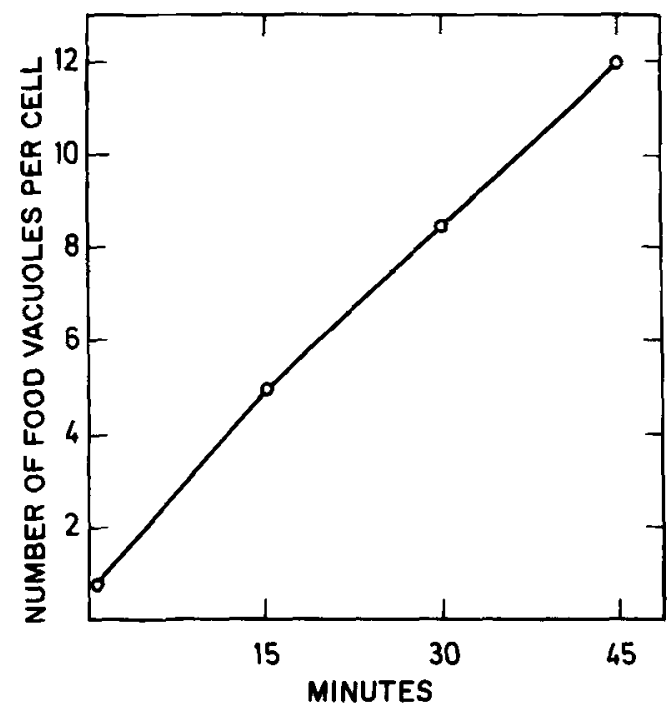

Figure 4. Number of food vacuoles per cell as a function of time. At time zero $1 \mathrm{ml}$ of a 0.1 per cent India ink suspension was added to a $10 \mathrm{ml}$ cell suspension of Tetrahymena pyriformis, strain GL, growing on 2 per cent proteose peptone broth supplemented with $2 \mathrm{mM}$ citrate and $0.036 \mathrm{mM}$ ferric chloride. Cell samples were fixed with 2 per cent formaldehyde (final concentration) at pre-selected time points. Food vacuoles were counted in 200 cells for each point.

of incubation and no more than 4 after a pariod of 30 minutes. Fig. 4 shows that the number of India ink labelled food vacuoles per average cell increased steadily throughout a period of 45 minutes at which time it amounted to 12 . The reason for this discrepancy in results obtained with two different markers is not known. The media are not identical. NILSSON's medium ( 2 per cent proteose peptone, liver extract and salts) contained a black precipitate which obscured the uptake of India ink and made it impossible to do the experiment in her medium with this marker.

\subsubsection{Food vacuoles and lysosomes}

Primary lysosomes are single-membraned vesicles containing acid hydrolase which has not yet been involved in digestive events (de DUVE (25)). T. pyriformis contains numerous slightly dense, oval or spherical vesicles varying in size from 0.5 to $1 \mu \mathrm{m}$ (ELLIOTT (26)). At the ultrastructural level they consist of fine granular material enveloped in a unit membrane and they have acid phosphatase activity (ELLIOTT (26)). NiLSSON (62) observed vesicles which she assumes to be primary lysosomes. They have an electron dense content and differ from those reported as primary lysosomes by ELLIOTT (26) with respect to size $(0.3 \mu \mathrm{m})$ and general morphology (laminated content). MULler, BaudHuin \& de Duve (60) isolated lysosomes from $T$. pyriformis and found that they contained five hydrolases - acid phosphatase, ribonuclease, deoxyribonuclease, protease and amylase. In the cells these lysosomes fuse with newly-formed food vacuoles and release their enzymes into the vacuoles thus transforming them into digestive vacuoles, or secondary lysosomes.

$T$. pyriformis secrete lysosomal enzymes to the extracellular fluid. SMITH (101) found that suspension medium contained four of the hydrolases mentioned above, even after brief incubation. DICKIE \& LIENER $(22,23)$ found the fifth: protease.

There is evidence for heterogeneity of lysosomes in $T$. pyriformis. MULLER (59) reported that the source of the hydrolases secreted into non-nutrient salt solutions was a special population of lysosomes characterized by its specific density. This secretion of enzymes was not influenced by the induction of food vacuoles. Furthermore, RoTHSTEIN \& BLUM (94) observed that ingested dimethylbenzanthracene particles did not cosediment with either acid phosphatase or ribonuclease activity. They suggested that either many of the particle-containing vacuoles did not fuse with lysosomes, or that those which did formed a class of food vacuoles which was separable from the acid phosphatase-rich lysosomes. BLUM \& RothsteIN (4) discussed the idea that maturation changes subsequent to the fusion between primary lysosomes and food vacuoles may contribute to the heterogeneity of the lysosomal population.

According to RICKETTS (89) feeding causes parallel stimulation of vacuole formation and of phosphatase activity in $T$. pyriformis. RICKETTS (92) also reported that latex particles in saline failed to induce endocytosis, and so did a variety of potentially digestible solutes studied singly in saline. However, some mixtures of 
solutes and latex particles in saline did induce endocytosis. Protein, polypeptides and RNA were highly effective inducers while glutamate, amino acid mixtures, polysaccharides and glucose were moderately effective. RICKETTS (91) also found that starved cells showed a marked periodicity in the rate of formation of vacuoles when they were presented with a mixture of peptone and polystyrene latex particles. He suggested that supply of energy and of lysosomes may be more important than supply of new membrane material for formation of vacuoles. NILSSON (63) also found periodicity in rates of formation of endocytic vacuoles.

It seems that the acidity of the food vacuole in Paramecium varies in a programmed fashion during the life of a vacuole (MAST (57), WiChTERMAN (110), Kitchings (53)). The same may happen in $T$. pyriformis. An increase in vacuolar acidity may make some compounds, otherwise unavailable to the cell, soluble as well as denature proteins and other macromolecules to facilitate enzyme action.

It is still unknown how the digestion products pass through the food vacuole membrane. WEIDENBACH \& THOMPSON (109) recently succeeded in isolating food vacuoles in vitro from $T$. pyriformis, so the necessary experimental material for solving this problem is now available.

\subsubsection{Egestion of food vacuoles}

Food vacuoles void their indigestible content through the cytoproct. Using the electron microscope AlLEN (2) studied this process in Paramecium caudatum. Just before the food vacuole emptied, its membrane fused with the plasma membrane in the cytoproct region of the cell; then after the content of the food vacuole was released into the suspension medium, the vacuole membrane underwent a transformation to form disc-shaped vesicles; these became part of the membrane pool. Apparently the vacuole membrane, at least in Paramecium caudatum, is not formed de novo at the time of food vacuole formation. Although the oral regions of Paramecium and Tetrahymena are different, ELLIOTT \& KENNEDY (29) and SATTLER (97) observed vesicles near the forming food vacuoles in $T$. pyriformis, and
WOLF \& ALLEN (106) saw that the food vacuole membrane was re-engulfed by endocytosis. In agreement with these observations the fecal pellets of $T$. pyriformis are not surrounded by membranes (Elliott \& Clemmons (28)).

According to BERGER (3) food vacuoles in Paramecium aurelia were not egested in the temporal order in which they were formed. $\mathrm{He}$ based his opinion on the following observation: cells incubated with radioactive bacteria formed food vacuoles whose egestion could be followed upon transfer of the cells to non-radiactive bacteria suspensions. The number of labelled food vacuoles per cell plotted against time decreased exponentially rather than linearly. This indicates randomness rather than sequential order in the expulsion of food vacuoles. A similar conclusion for T. pyriformis was reached by ROTHSTEIN \& BLUM (93).

ROTHSTEIN \& BLUM (93) observed that colchicine, vinblastine and cytochalasin $\mathbf{B}$, all of which inhibited particle ingestion, did not interfere with particle egestion. They stated that this points to a significant difference between ingestion and egestion mechanisms.

\subsubsection{Efficiency of particle collection}

The undulating membrane and the three membranelles of the oral apparatus beat fast and incessantly in intact cells. This creates a current of fluid with suspended material flushing the buccal cavity, the cytopharynx and perhaps even the receiving vacuole. This results in a collection of particulate material, probably assisted by mucus present in these cavities (see section 2.1.9). COX (19) and RASMUSSEN, BUHSE $\&$ GROH (81) measured the rates with which India ink particles disappeared from the suspension medium. The results agreed well. The latter authors found that the volume of extracellular fluid cleared of particles by the cells was about 500-fold larger than the volume of food vacuoles formed in the same time. Thus $T$. pyriformis is very efficient in collecting small particles from large volumes of suspension medium.

\subsubsection{Total volume of food vacuoles formed in a generation time}

RASMUSSEN (80) found that cells suspended in a 
chemically defined medium formed food vacuoles which had a total volume of about 50 per cent of the average cell volume in a generation time. CHAPMAN-ANDRESEN \& NILSSON (13) calculated the average volume of a newly-formed food vacuole $(0.2$ per cent of the average cell volume) in cells grown in the standard proteose peptone medium, and NILSSON (63) reported that the cells formed about 60 food vacuoles per cell generation under identical conditions. From the two sets of values it can be calculated that the total volume of vacuoles formed in a cell generation time is about 15 per cent of the average cell volume. We have no estimate of the volume of food vacuoles formed per cell generation in cells feeding on bacteria, but it is quite possible that values higher than those quoted above can be obtained under these conditions. Extreme, low values (probably $<1$ per cent of those given above) are found in the so-called food-vacuole-less cells, NP1 (see section 3.1.1.1.).

\subsubsection{Area of food vacuole membranes}

Chapman-ANDRESEN \& Nilsson (13) calculated that one newly-formed food vacuole represented a surface area equal to 1.6 per cent of the cell surface of an average cell. In 2 per cent proteose peptone medium, enriched with 0.4 per cent liver fraction $L$ and salts (PLESNER, RASMUSSEN \& ZEUTHEN (76)) they showed that exponentially-growing $T$. pyriformis, strain GL, had an average generation time of about 2.5 hours, made an average of 1 food vacuole per 3 minutes, forming about 50 food vacuoles per generation time. Thus the food vacuole membrane made available in a generation time equalled $50 \times 1.6$ per cent of a cell surface, or about 80 per cent of the cell surface.

There are thirty food vacuoles per average cell grown under the experimental conditions described above. The average food vacuole has a diameter of $3.5 \mu \mathrm{m}$ (RASMUSSEN, unpublished observations). Thus it can be calculated that the membrane area available for transport of nutrients from vacuoles into the cytoplasm at any time in the average cell is in the range of 20 per cent of the cell surface under these conditions.

\subsubsection{Mucus}

Mucus material is extruded from small argentophilic granules situated under the cell surface. They have been called protrichocysts (PITElKa (74)), mucigenic bodies (PITELKA (75)), and more recently, mucocysts (TOKUYASU \& SChERbaUm (105), NilsSON \& BEHNKE (65), SatiR, SChOoley \& SATIR (96) and SATIR (95). These granules also appear under the cell surface in the buccal cavity (WILLIAMS \& LUFT (112) and Nilsson, (63)). Nilsson \& BEHNKE (65) observed that $T$. pyriformis from the stationary growth phase were coated by a mucosubstance approximately $0.02 \mu \mathrm{m}$ thick. Cells from the exponential growth phase exhibited no such surface layer.

NILSSON (63) proposed that this mucus plays a role in uptake processes: it may adsorb nutrients prior to being enclosed in the food vacuoles. A similar role has been established for the hair-like extensions of the plasmalemma of the large amoebae (CHAPMAN-ANDRESEN \& Holter (12)) - see section 3.1.1.4. There is no experimental evidence as yet for concentrative adsorption of any nutrient in the case of $T$. pyriformis (compare section 3.2.1). NILSSON (63) observed, however, that the mucus of the extruded mucocysts stained with alcian blue and then appeared with a more intense colour than the surrounding solution, indicating an adsorption of the dye to the extruded mucous material.

The mucus may also play a part in retaining food particles swept into the buccal cavity and the receiving vacuole by the beating action of the undulating membrane and the three membranelles.

\subsubsection{Other phagocytic vacuoles}

It is still not known if $T$. pyriformis forms phagocytic vacuoles from the cell surface other than the food vacuoles described above.

\subsubsection{Summary}

The oral structures of $T$. pyriformis efficiently collect small particles in the food vacuoles. The vacuoles fuse with lysosomes carrying digestive enzymes; uptake of digestion products then occurs by unknown mechanisms through the food vacuole membrane. Dissolved nutrients 
may be present in the mucus of the food vacuoles in higher concentrations than in the suspension medium.

The food vacuoles may be considered cellular compartments in which the chemical environment can be changed to promote release of compounds from previous physical and chemical combinations, serving to facilitate their uptake. The same purpose is likely to be served by water uptake from the vacuole leading to its shrinkage and to increase in concentrations of enclosed dissolved compounds. The phagocytic vacuoles enlarge the area of the transporting surfaces of the cell.

\subsection{Pinocytic Vacuoles and Vesicles}

Several authors reported cytoplasmic vacuoles or vesicles, to which they have attributed functions in nutrient uptake in $T$. pyriformis. EllotT \& Clemmons (28) found clear vacuoles near the plasma membrane which they interpreted to be pinocytic vacuoles. These vacuoles appear to be about $2 \mu \mathrm{m}$ in diameter. Their origin is unknown, but it is stated that they are often seen in the vicinity of breaks in the plasma membrane described as regions through which the content of mucocysts has been discharged (ELLIOTT \& KENNEDY (29)).

ALLEN (1) saw cisternae with smooth membranes in the subpellicular cytoplasm. These smooth-membraned cisternae frequently had at their margins enlargements coated on their cytoplasmic surfaces with bristles similar in appearance to those coating the parasomal sacs, and indeed a direct connection between the two systems is possible. The parasomal sacs are indentations of the outer membrane found just anterior to each kinetosome or basal body of the cilium (PITElKa (75)). Thus the membrane of the cisternae might be continuous with the outer pellicular membrane. ALLEN (1) proposed that the parasomal sacs are sites of selective uptake of certain large molecules, such as proteins. According to him the outer membrane could give rise to the smooth-membraned cisternae, and these could pinch off vesicles carrying loads of externally adsorbed molecules into the cell by a process similar to pinocytosis.

WILLIAMS \& LUFT (112) observed a system of surface pits and associated membrane-bound cisternae with a diameter of about $0.1 \mu \mathrm{m}$ throughout the oral and somatic regions. They noted that the parasomal sacs were somewhat similar in morphology to the coated vesicles known from certain metazoan cells in which they transport absorbed protein into epidermal cells (FRIEND \& FARQUHAR (33)). WILLIAMS \& LUFT (112) suggested that the pits and cisternae might function in $T$. pyriformis in a similar way. We do not know how often these vesicles are formed, and we do not know their number per cell. Hence we cannot assess their quantitative role for nutrient uptake.

It is not known if other types of vesicles participate in nutrient uptake.

It is a far cry from the static electron micrographs of the small vesicles in $T$. pyriformis to a demonstration of their role in food uptake. It will be shown in section 3.1.1.1. that cells without food vacuoles suspended in a rich, standard proteose peptone broth are incapable of sustained growth and division. Thus these small vesicles cannot fulfill the nutrient requirement for rapid multiplication under these experimental conditions.

It is regrettable that our knowledge of food uptake at levels different from those of the phagocytic vesicles in T. pyriformis is so scanty, when compared to our knowledge of pinocytosis in the large amoebae. Here extensive and fruitful studies have revealed the importance of adsorption of charged molecules, the existence of inducers of pinocytosis, and the timing and the extent of the uptake of both high- and low- molecular weight compounds: for reviews see HOLTER $(44,45,46)$ and CHAPMAN-ANDRESEN $(7,8,9)$ and for original reports see Holter \& MARShall (47), ChapMAN-ANDRESEN \& HOLTER $(11,12)$, ChAPMAN-ANDRESEN \& PREscotT (14), Cha PMAN-ANDRESEN (6), Chapman-ANDRESEN \& Christensen (10), HENDIL (39) and BRANDT \& HENDIL (5).

\subsection{The Plasma Membrane}

The surface of $T$. pyriformis encompasses a variety of structures: cilia, fibers, mucocysts etc. (see ElLIOTT \& KENNEDY (29) for a recent review). The cell is enclosed in a system of membranes which all show the unit membrane 
structure (PItelka (75) and TokuYasu \& SCHERBAUM (105)). The outer membrane, the plasma membrane, covers the entire surface of the cell, also the cilia; immediately beneath the plasma membrane is a mosaic of flat, membrane-bounded "alveoli"; cilia and mucocysts emerge from the underlying ectoplasm between adjacent alveoli (PrTElKA (75)). Because it has been suggested that the outer surface of $T$. pyriformis is extended by "pits", "sacs", or by "cisternae" - stretching deep into the cell - in periodic or permanent open connection with the surroundings, it is difficult to define what distinguishes nthe outer cell surface" from "the inner cell surface Operationally, these inner surfaces could be extensions of the outer surface and for my purpose they will be treated as such. Thus all nutrients which are taken up by the outer cell surface pass the plasma membrane.

It will be shown later that the plasma membrane seems to be permeable to the majority of the nutrients which $T$. pyriformis requires for rapid growth and multiplication and it will be shown that the cell seems to have specific uptake sites for a number of compounds, such as carbohydrates, amino acids etc. Nothing is known about the structure of the single transport sites, nor about their distribution on the cell surface.

\section{ON NUTRIENT UPTAKE}

Detailed information on food uptake i $T$. pyriformis is scarce. One reason is that several types of organelles participate in the uptake processes. Another, that the relative contributions of these organelles may vary in media of different composition. The possible roles of food vacuoles, vesicles and the cell surface will be discussed below.

\subsection{Nutrient Uptake by Membrane Invaginations}

This section deals with the role of food vacuoles and vesicles in food uptake. The significance of these structures is evaluated from the aspect of how well they contribute towards uptake of all nutrients required for reasonably fast cell growth and multiplication.

\subsubsection{The roles of the food vacuoles}

$T$. pyriformis grows well both in complex nutrient media (proteose peptone broth with or without supplements) and in chemically defined solutions. Many nutrients are required including amino acids, vitamins, nucleosides and salts (KIDDER \& DEWEY (52)). The minimum generation times under optimum conditions are less than 2 hours for $T$. pyriformis, syngen 1, (optimum temperature: about $37^{\circ} \mathrm{C}$ (RASMUSSEN, unpublished observations)) and 2.5 hours for $T$. pyriformis, strain GL (optimum temperature: $28^{\circ} \mathrm{C}$, THORMAR (104)).

T. pyriformis grows and forms many food vacuoles in the nutrient media traditionally used (section 2.1.1), and cells which form few or no food vacuoles do not grow (RASMUSSEN \& KLUdT (82), RASMUSSEN \& ModeWEg-HANSEN (83), Hoffmann, Rasmussen \& Zeuthen (43), Orias \& Pollock (70) and RAsmussen \& OrIas (84)). However, it has been found that the cells can grow without forming food vacuoles, provided that the media are enriched in certain defined ways (RASMUSSEN \& KLUDT (82), RASMUSSEN (79), HofFMANN, RASMUSSEN \& ZEUTHEN (43) and RASMUSSEN \& ORIAS (84)). These observations have formed the basis for experiments carried out in order to characterize the roles of the food vacuole in nutrient uptake. The following pages present results of experiments designed to show whether or not all compounds required for continued cell multiplication could be taken up by the cells under different sets of conditions. All compounds were judged to be taken up, if the cells kept multiplying with normal generation times under the new experimental conditions. On the other hand, if the cells grew very slowly or ceased to multiply, it was concluded that they had failed in taking up one or more of the essential nutrients.

\subsubsection{Cell multiplication and reduced food vacuole formation}

RASMUSSEN \& KLUDT (82) reported that $T$. pyriformis, strain GL, suspended in autoclaved and filter-sterilized proteose peptone broth multiplied with generation times of 6 and $>40$ hours, respectively. The cells in the autoclaved proteose peptone medium contained many 
Multiplication of two lines of Tetrahymena pyriformis, syngen 1 , in the chemically defined medium with various supplementations.

\begin{tabular}{|c|c|c|c|c|c|c|}
\hline \multirow[b]{3}{*}{ Medium } & \multicolumn{6}{|c|}{ Cell concentrations per $\mathrm{ml} \times 10^{-3}$. } \\
\hline & \multicolumn{3}{|c|}{$\begin{array}{l}\text { NPl cells forming no } \\
\text { food vacuoles }\end{array}$} & \multicolumn{3}{|c|}{$\begin{array}{l}\text { DIll cells forming } \\
\text { food vacuoles }\end{array}$} \\
\hline & Oh & $18 \mathrm{~h}$ & $43 \mathrm{~h}$ & $\mathrm{Oh}$ & $18 \mathrm{~h}$ & $43 \mathrm{~h}$ \\
\hline \multirow{4}{*}{$\begin{array}{l}\text { a. } \mathrm{DM} \\
\text { b. } \mathrm{DM}+\mathrm{Fe} \& \mathrm{Cu} \\
\text { c. } \mathrm{DM}+\text { folinic acid } \\
\text { d. } \mathrm{DM}+\mathrm{Fe} \& \mathrm{Cu}+ \\
\text { folinic acid }\end{array}$} & 5 & 5 & 4 & 5 & 300 & 550 \\
\hline & 5 & 8 & 10 & & & \\
\hline & 5 & 4 & 4 & & & \\
\hline & 5 & 36 & 300 & 5 & 300 & 500 \\
\hline
\end{tabular}

DM: chemically defined medium (HoLz et al. (49)); Fe: ferric chloride $(900 \mu \mathrm{M})$; Cu: copper sulphate $(30 \mu \mathrm{M})$; folinic acid: $2 \mu \mathrm{M}$; time zero: cell concentration at inoculation. General conditions: source of inocula: cells subjected to two transfers in unsupplemented DM; temperature $37^{\circ} \mathrm{C}$. Unpublished data, ORIAS \& RASMUSSEN .

food vacuoles (see section 2.1.1.) and observations of live cells from this nutrient medium showed frequent formation of food vacuoles. On the other hand, cells from the filtered medium showed no food vacuole formation: 20 single cells from the filter-sterilized medium were kept under continuous observation each for a period of 10 to 15 minutes, and no vacuoles were seen to be formed during the total observation period of 4 hours (RASMUSSEN, unpublished).

The slow cell multiplication in the filter-sterilized broth was probably a result of lack of food-vacuole-inducing particles, since addition of particulate materials such as clay, iron, aluminium hydroxide particles (RASMUSSEN \& KLUDT (82)), polystyrene particles, heat-coagulated egg albumin (RASMUSSEN \& MODEWEG-HANSEN (83)) and India ink particles (RASMUSSEN, unpublished observations) stimulated cell growth back to control values.

Multiplication of $T$. pyriformis, strain GL, with reduced food vacuole formation could also be stimulated by addition of specific nutrients in high concentrations. RASMUSSEN (79) found that addition of glucose and nucleosides in rather high concentrations promoted multiplication substantially; again direct observation of live cells in the microscope failed to reveal any formation of food vacuoles. Nilsson, RicketTs \& Zeuthen (66) showed that cytochalasin B reduced formation of food vacuoles in $T$. pyriformis. HoFFMANN, RasmusSEN \& ZEUTHEN (43) found that the inhibitor also decreased multiplication rates of cells in the nutrient medium, and observed that glucose and nucleosides relieved this effect, while having no effect on vacuole formation.

These studies have been extended to other cells without food vacuole formation. ORlas \& POLLOCK (69) isolated a cell line, NPl, in which food vacuole formation could be controlled. The cell line was derived from $T$. pyriformis, syngen 1 , mating type III, inbred family $D$. The $\mathrm{NPl}$ cells did not form food vacuoles at $37^{\circ} \mathrm{C}$ as observed by optical microscopy (ORIAS \& POLLOCK (70)) - see Fig. 5 - and by transmission electron microscopy (ORIAS, CHARVat, LiNG \& POLLOCK (68); NILSSON, personal communication). They formed, however, normal food vacuoles at $28^{\circ} \mathrm{C}$. NPI cells without food vacuoles ceased to multiply in standard proteose peptone media at $37^{\circ} \mathrm{C}$ (OrIAs \& POLLOCK (69); RASMUSSEN, unpublished observation). However, the cells could be grown for hundreds of generations, if the nutrient media were enriched with high concentrations of both trace metal salts and of vitamins (RASMUSSEN \& ORIAS (84)). The cell generation times of the NPl cells were about twice as long as those of the DIII wild-type cells under these conditions (RASMUSSEN \& ORIAS $(84,85)$ and ORIAS \& RASMUSSEN $(71,72)$ ). Further studies 

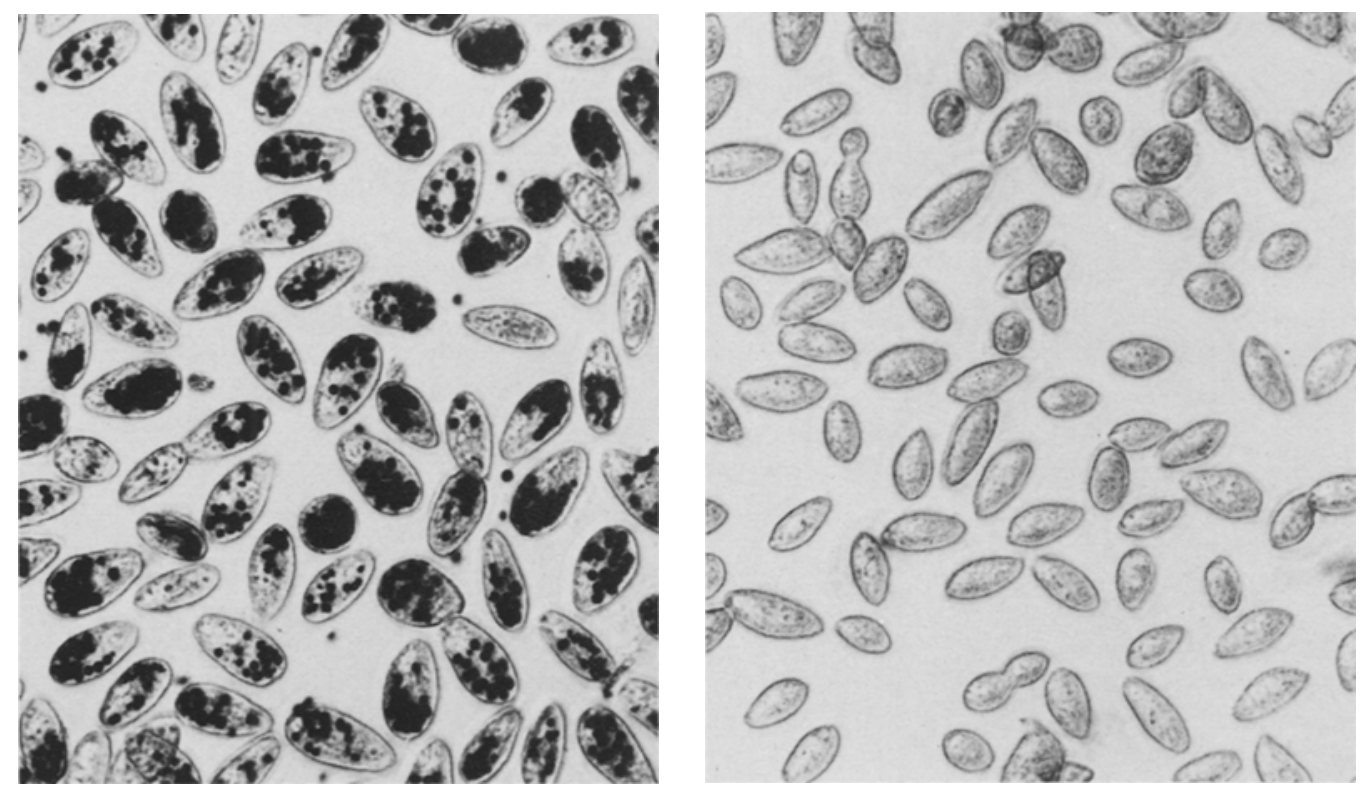

Figure 5. Appearance of Tetrahymena pyriformis, syngen 1, DIII (left) and NP1 (right) grown at $37^{\circ} \mathrm{C}$ in enriched proteose peptone and exposed to India ink. Late exponential phase cultures were exposed to 0.01 per cent India ink (final concentration) at $37^{\circ} \mathrm{C}$ for approximately 60 minutes, fixed with 2 per cent formaldehyde (final concentration), concentrated by low speed centrifugation and observed under the microscope.

showed that the mixture of trace metal salts could be replaced with iron and copper salts alone, and the vitamins could be replaced with folinic acid alone (ORIAS \& RASMUSSEN (71) and RASMUSSEN \& ORIAS (85)). These additions also promoted growth in the defined medium (Table I), and the growth rates shown in line $d$ could be maintained for hundreds of generations (ORIAS \& RASMUSSEN (72) and unpublished observations).

In conclusion, $T$. pyriformis could grow and multiply in enriched media in spite of strongly reduced food vacuole formation. Their growth rates were about half of those of the food-vacuole-forming cells under the same conditions. Different strains of $T$. pyriformis required supplements of different nutrients.

\subsubsection{Cell multiplication and particulate material}

RASMUSSEN \& ORIAS (unpublished observations) showed that heat-coagulated, particulate egg albumin could supply cells which formed food vacuoles (D III) with all of the amino acids required for growth, whereas cells which formed no food vacuoles (NPl) starved on the same diet (Table II, line c). Furthermore, CURDS \& CockBuRN (21) showed that $T$. pyriformis could grow and divide with short doubling times in bacteria suspensions multiplying in solutions of sucrose and salts. Apparently, the food vacuoles could provide most, if not all, of the nutrients the cells required for rapid multiplication when the food was present in the form of particles. Thus food vacuoles seem to be indispensable for the uptake of particulate nutrients.

The effect on cell multiplication of particulate material without apparent nutritional value has been studied in filter-sterilized proteose peptone broth. As already mentioned $T$. pyriformis, strain GL, grew poorly in this medium. RASMUSSEN (unpublished) observed that India ink particles stimulated growth well in this medium. RASMUSSEN \& MODEWEGHANSEN (83) found that addition of polystyrene particles resulted in improved growth. Both of these types of particles induced food vacuole formation (see section 2.1.2) and, in turn, apparently stimulation of nutrient uptake. Cell 
multiplication rates, therefore, appear to be stimulated also by particles which are not nutritious themselves.

\subsubsection{On the role of the food vacuole}

The normal, wild-type, syngen 1 cells formed food vacuoles and grew in media whose concentrations of $\mathrm{Fe}, \mathrm{Cu}$ and folinic acid were much lower than those required by the food-vacuole-less NPI cells (Table I, line $a$ ). What do these results mean? $\mathrm{Fe}, \mathrm{Cu}$ and folinic acid may be taken up in NPI cells by the cell surface or by vesicles other than the food vacuoles. This seems to require higher than normal extra-cellular nutrient concentrations, reflecting poor surface penetration, small vesicular volumes, or both. In any case, as judged by the growth rates, the uptake of these compounds was greatly facilitated when food vacuoles were present (Table 1, lines $a$ to $c$ ). Chemical features of food-vacuolar uptake of $\mathrm{Fe}, \mathrm{Cu}$ and folinic acid are largely unknown. We do not know why the food vacuole was more efficient than the cell surface in the uptake of certain nutrients. ORIAS \& RASMUSSEN (71) pointed out features which may or may not be important. Firstly, the oral structures are well suited to collect particles (see section 2.1.6.). Secondly, the cell might be able to bring insoluble salts (of iron, for example) in solution by lowering of the $\mathrm{pH}$ value of the food vacuole (see section 2.1.4). Thirdly, it is possible, but not yet demonstrated that uptake is facilitated by shrinkage of the food vacuole. Lastly, it is possible, but again not demonstrated, that the food vacuole membrane has transport abilities which are different from those of the plasma membrane. In this context it is of interest that CHAPMAN-ANDRESEN \& HOLTER (11) working with amoebae found glucose, to which the plasmalemma is impermeable, in the cytoplasm after induction of pinocytosis by addition of protein. So far the reason for this change in transport capacity is unknown.

The reason why different strains of $T$. pyriformis need different nutrients in excess concentrations is not understood.

ORIAS \& RASMUSSEN (unpublished observations) attempted to evaluate the role of the food vacuole in uptake of dissolved protein. They cultivated normal, food-vacuole-forming wildtype cells in a chemically defined medium in which either the whole amino acid complement, or leucine, or phenylalanine was replaced by dissolved egg albumin (Table III, lines $e, f$ and $g$ ). This tested if the protein in solution could supply all the amino acids required, or leucine, or phenylalanine fast enough to allow the cells to grow and multiply with generation times which could be considered reasonably short for $T$. pyriformis, namely generation times of a few hours. In no case where the cells had to rely on soluble egg albumin for a supply of amino acids was a full doubling observed during

\section{Table II}

Food vacuoles are required for utilization of particulate egg albumin as an amino acid source; dissolved egg albumin cannot serve as an amino acid source.

\begin{tabular}{l|r|r|r|r|r|r}
\hline & \multicolumn{5}{|c}{ Cell concentrations per 1 $\times 10^{-3}}$. \\
\cline { 2 - 7 } & \multicolumn{3}{|c|}{$\begin{array}{c}\text { NPI cells forming no } \\
\text { food vacuoles }\end{array}$} & \multicolumn{3}{c}{$\begin{array}{c}\text { DIII cells forming } \\
\text { food vacuoles }\end{array}$} \\
\cline { 2 - 7 } Medium & $0 \mathrm{~h}$ & $18 \mathrm{~h}$ & $43 \mathrm{~h}$ & $0 \mathrm{~h}$ & $18 \mathrm{~h}$ & $43 \mathrm{~h}$ \\
\hline a. EDM & 5 & 40 & 190 & 5 & 305 & 300 \\
b. EDM - a.a. & 5 & 2 & 1 & 5 & 6 & 5 \\
c. EDM - a.a. + EA & 5 & 2 & 1 & 5 & 307 & 395 \\
d. EDM - a.a. + EA & 5 & 2 & 5 & 5 & 9 & 8 \\
\hline
\end{tabular}

EDM: enriched chemically defined medium (Table I, line $d$ ); a.a.: amino acid complement of the defined medium; $\mathrm{EA}_{\mathrm{h}}$ and $\mathrm{EA}_{\mathrm{s}}$ :heat-coagulated and dissolved egg albumin, $0.1 \%$; time zero: cell concentrations at inoculation. General conditions: source of inocula: amino acid depleted cells; temperature: $37^{\circ} \mathrm{C} ; \mathrm{pH}$ : 7 . Unpublished data, ORIAS \& RASMUSSEN. 
Egg albumin replaces neither the whole amino acid complement, nor leucine, nor phenylalanine in the chemically defined medium for growth of Tetrahymena pyriformis, syngen 1, strain DIII.

\begin{tabular}{|c|c|c|c|c|}
\hline \multirow[b]{2}{*}{ Medium } & \multicolumn{3}{|c|}{ Cell concentrations per $\mathrm{ml} \times 10^{-3}$. } & \multirow{2}{*}{$\begin{array}{c}\text { Cell doubling } \\
\text { times }\end{array}$} \\
\hline & Oh & $18 \mathrm{~h}$ & $45 \mathrm{~h}$ & \\
\hline a. DM & 5 & 305 & 300 & ca. $3 \mathrm{~h}$ \\
\hline b. DM-a.a. & 5 & 6 & 5 & $>45 h$ \\
\hline c. DM-leu & 5 & 6 & 6 & $>45 \mathrm{~h}$ \\
\hline d. DM-phe & 5 & 5 & 6 & $>45 \mathrm{~h}$ \\
\hline e. $D M-a . a .+E A_{s}$ & 5 & 9 & 8 & $>45 \mathrm{~h}$ \\
\hline f. $D M-l e u+E A_{s}$ & 5 & 6 & 8 & $>45 \mathrm{~h}$ \\
\hline g. $D M-p h e+E A_{s}$ & 5 & 8 & 8 & $>45 \mathrm{~h}$ \\
\hline h. $D M-$ a.a. $+E A_{h}$ & 5 & 194 & 340 & ca. $3 \mathrm{~h}$ \\
\hline i. $\quad D M+E A_{S}$ & 5 & 307 & 395 & ca. $3 \mathrm{~h}$ \\
\hline
\end{tabular}

DM: the chemically defined medium of HoLz et al. (49); a.a.: amino acids; $\mathrm{EA}_{\mathrm{s}}$ and $E \mathrm{~A}_{\mathrm{h}}$; dissolved and heatcoagulated egg albumin, $0.1 \%$; time zero: cell concentrations at inoculation. General conditions: source of inocula: amino acids depleted cells; temperature: $37^{\circ} \mathrm{C}$. Unpublished data, ORIAS \& RASMUSSEN .

a period of 45 hours. Tests were included to show that dissolved egg albumin did not inhibit cell multiplication in the complete medium (line $i$ ) and that heat-coagulated, particulate egg albumin indeed supplied all the essential amins acids for $T$. pyriformis (line $h$ ). Two series of experiments have been made: in one (not shown) separate addition of insoluble iron and Sephadex particles ensured that the cells formed food vacuoles; this did not affect cell multiplication.

These results showed that the cells could utilize particulate egg albumin much better than the same protein in solution, and cells which were incubated with particulate egg albumin had indeed their food vacuoles packed with lumps of coagulated protein not seen in the cells fed dissolved albumin. Thus the difference in multiplication rates may be explained by the different concentrations of nutrients in the food vacuoles. Other interpretations are possible: VISWANATHA \& LIENER (108) suggested that similar results could be explained if the digestive enzymes of the food vacuoles were less efficient in attacking native, than denatured protein. Although this is probably true its significance in nutrient uptake is difficult to assess.

In the large amoebae it has been established that a positive electric net-charge of a protein promotes its adsorption to the mucous layer of the cell surface (CHAPMAN-ANDRESEN (6); ChAPMAN-ANDRESEN \& Christensen (10)). The nutrient medium in the experiments mentioned above was maintained at $\mathrm{pH} 7.0$ and the isoelectric point of egg albumin is around a $\mathrm{pH}$-value of 4.8. Thus the egg albumin had a negative net-charge in these experiments. It will be of interest to see if $T$. pyriformis can utilize dissolved proteins with a positive charge fast enough for rapid cell multiplication.

\subsubsection{Food vacuole volumes and nutrient uptake}

LWOFF (55) stated that $T$. pyriformis could grow and multiply without food vacuoles. His statement would imply that there is not necessarily any relation between food vacuole volumes and nutrient uptake, but it has so far had no impact on the discussion on food uptake in Tetrahymena. Since then, several authors have shown that the volume of food vacuoles made per unit time, multiplied by the concentration of a certain compound in the suspension medium, could not account for the amount of that nutrient taken up by the cells. Thus SEAMAN $(98,99)$ calculated that only 2 per cent of consumed acetate entered $T$. pyriformis through food vacuoles. Pruett, Conner \& Pruett (77) showed that accumulation of orthophosphate far exceeded the capacity of the food vacuole 
volumes. NILSSON (63) found that the food vacuole volume could not account for bringing in nutrients in sufficient amounts to allow the cells to double their dry weight in a generation time. Finally, RASMUSSEN (80) calculated that food vacuole volumes were insufficient for the uptake of nucleosides from a chemically defined medium.

These observations were interpreted in different ways. Seaman $(98,99)$ proposed that acetate could be taken up through the cell surface; Pruett, Conner \& PruetT (77) were inclined to assume that a highly selective binding site in the oral region allowed initial concentration of phosphate; NiLSSON (63) proposed that nutrients were concentrated in the mucous substance of the food vacuole prior to uptake. This latter proposal was made in analogy with CHAPMAN-ANDRESEN \& HOLTER's (12) results on Amoeba proteus which showed that serum albumin was concentrated about 36 -fold in the mucus of the amoebae prior to uptake. RASMUSSEN (80) proposed that uptake of nutrients could occur through the cytopharyngeal membrane before the food vacuole is formed. Thus all authors agreed that mechanisms exist which either concentrate nutrients prior to, or concomitant with, their uptake through vacuoles, or which transport nutrients into the cells through parts of the surface which may or may not be associated with the feeding apparatus.

\subsubsection{Summary}

T. pyriformis could grow and multiply in absence of food vacuole formation, provided the nutrient media were strongly supplemented. Different strains were not identical with respect to their requirements for excess concentrations of nutrients. The biochemical foundation for promotion of food uptake by the food vacuole is not known.

The food vacuoles were very effective in collecting and processing particulate food, such as bacteria and heat-coagulated egg albumin. In contrast, food vacuoles could not supply the cells with amino acids from dissolved egg albumin fast enough to sustain rapid cell multiplication.

\subsubsection{The roles of vesicles}

Morphological investigations have shown that vesicles are formed from the surface of the oral region and possibly also from the cell surface (section 2.2). These vesicles tend to be small. WiLliams \& LUFT (112) showed the presence of vesicles with a diameter of about $0.1 \mu \mathrm{m}$, or about 2 per cent of the diameter of a newly-formed food vacuole. This means that the volume of one food vacuole is about 100,000 -fold larger than that of one vesicle. No studies have yet shown how many types of vesicles are formed, or with what frequency they appear.

No direct measurements of the contribution

\section{Table IV}

Growth of three lines of Tetrahymena pyriformis in filter-sterilized and heat-sterilized proteose peptone broth.

\begin{tabular}{l|c|c|c|c|c|c|}
\hline \multirow{2}{*}{} & \multicolumn{4}{|c}{ Cell concentrations per $\mathrm{ml} \times 10^{-3}}$. \\
\cline { 2 - 7 } & \multicolumn{3}{|c|}{$\mathrm{PP}_{\mathrm{f}}$} & \multicolumn{3}{c}{$\mathrm{PP}_{\mathrm{h}}$} \\
\cline { 2 - 7 } & $0 \mathrm{~h}$ & $18 \mathrm{~h}$ & $\left.43 \mathrm{~h}^{*}\right)$ & $0 \mathrm{~h}$ & \multicolumn{3}{|c}{$18 \mathrm{~h}$} & $43 \mathrm{~h}$ \\
\hline a. Syngen 1, strain DIII & 1 & 2 & 3 & 1 & 43 & 210 \\
b. Syngen 1, strain NPI & 1 & 3 & 4 & 1 & 40 & 230 \\
c. Strain GL & 1 & 3 & 4 & 1 & 39 & 220 \\
\hline
\end{tabular}

$\mathrm{PP}_{\mathrm{f}}$ and $\mathrm{PP}_{\mathrm{h}}: 2 \%$ proteose peptone broth, sterilized by filtration and by heating, respectively; time zero; cell concentrations at inoculation. General conditions: cells were starved for $24 \mathrm{~h}$ and then transferred to medium of the above description; 24 hours later the cells were inoculated at 0 hours; temperature $28^{\circ} \mathrm{C}$. Unpublished data, ORIAS \& RASMUSSEN.

*) No increase in size is seen in these cells. 
towards nutrient uptake by these vesicles have been made. We may infer that they cannot bring into the cell all the required nutrients at a fast rate, since three cell lines of $T$. pyriformis grew very poorly in filter-sterilized media compared to the cells having food vacuoles in the autoclaved proteose peptone broth (RASMUSSEN \& KLUDT (82) and Table IV). The same argument can be applied to NPI cells without food vacuoles suspended in 2 per cent proteose peptone broth or in the chemically defined medium, both of which support fast growth of the wild type cells: the mutant cells do not multiply in these media (RASMUSSEN \& ORIAS (84)). Therefore it can be concluded that the summed activity of all non-food-vacuolar vesicles is in no way sufficient to supply all the nutrients in amounts required for reasonably fast continued growth and multiplication under these conditions. Such vesicles also failed to take up either heat-denatured or dissolved egg albumin at a rate fast enough to support continued cell multiplication (Table II, lines $c$ and $d$, respectively). However, it is possible that the vesicles may take up specific nutrients present in high concentrations in the medium in which the NPI cells grow. Enriched media which support growth of these cells contain $\mathrm{Fe}, \mathrm{Cu}$ and folinic acid in much higher concentrations than those required for growth of normal cells.

The whole question of small vesicles is unclear, but a good survey of them is given by NILSSON (64, see Fig. 7 in this reference). Some of the small vesicles may be membrane recycling vesicles, others membrane renewal vesicles, i.e. adding rather than removing membranes at the cytopharynx, while still others may be micropinocytic, in any case their contribution to uptake is unknown, and until satisfactory electron microscope tracer experiments are made, no clarification of this problem can be expected. Such experiments have been in progress for a year in collaboration between Drs. J. NiLsSON, E. ORIAS and the author.

In conclusion, $T$. pyriformis contain many vesicles which are smaller than the food vacuoles some of which may be pinched off from the plasma membrane by pinocytosis.

These vesicles are not likely to make a major contribution to the cells' overall nutrition, but they may have significant qualitative roles in the uptake of specific nutrients.

\subsection{Nutrient Uptake without Membrane Invagination}

This section deals mainly with uptake through the plasma membrane, that is, uptake without participitation of membrane invagination as typified by food vacuole formation, and without quantitatively significant formation of other vesicles.

\subsubsection{The roles of the plasma membrane}

It is important to decide if carrier-mediated uptake of nutrients occurs in $T$. pyriformis. In the following discussion some results which throw light on this problem are presented:

(i) The oral apparatus partially dedifferentiated (WILLIAMS \& ZEUTHEN (115)) and food vacuole formation ceased for a period of about 20 minutes before cell division (CHAPMANANDRESEN \& NILSSON (13)). CROCKETT, DUNHAM \& RASMUSSEN (20) found that the incorporation of radioactive phenylalanine and histidine administered separately in short pulses occurred at nearly constant rates in heat-synchronized cells (SCHERBAUM \& ZEUTHEN (100)) studied in an otherwise inorganic salt solution (HAmburger \& Zeuthen (38)). This showed that these amino acids could be taken up during the period in which no food vacuoles were formed.

(ii) HOFFMANN \& RASMUSSEN (41) measured the initial rates of methionine uptake in the presence and absence of food-vacuole-inducing particles. These rates were independent of food vacuole formation. LING \& ORIAS (personal communication) measured the rates of uptake of L-phenylalanine using wild type cells in the absence and presence of food-vacuole-inducing particles, and in the food-vacuole-less mutant, NPl. They found no significant differences. Overall uptake rates are, therefore, not measurably influenced by the activity of the food vacuoles.

(iii) ORIAS \& RASMUSSEN (71) showed that the requirements for each of the four vitamins nicotinic acid, pantothenic acid, pyridoxal, and riboflavin-5'-P were similar in food-vacuoleproducing wild type and in food-vacuole-less 
NPI cells. This suggested that uptake of these vitamins by the food vacuole could not play any essential role. Uptake must occur across the plasma membrane or by micropinocytosis, if the latter has any quantitative significance.

(iv) Several groups of investigators studied uptake of phenylalanine in $T$. pyriformis. STEPHENS \& KERR (102), HOFFMANN \& RASMUSSEN (41) and LING \& ORIAS (personal communication found that the uptake showed saturation kinetics, and STEPHENS \& KERR (102) and LING \& ORIAS (54) found that it was stereo-specific, temperature-dependent and inhibitable with 2,4-dinitrophenol, which is apparantly an uncoupler of oxidative phosphorylations in $T$. pyriformis (HAMBURGER \& ZEUTHEN (38)). Uptake of methionine also showed saturation kinetics and was stereo-specific (HOFFMANN \& RASMUSSEN (41)).

Uptake of nucleosides has also been studied. Freeman \& MONER $(31,32)$ and Wolfe $(118)$ found that uptake of uridine by $T$. pyriformis showed saturation kinetics. FREEMAN \& MONER (32) reported that thymidine, deoxyguanosine, deoxycytidine, deoxyadenosine, 6mercaptopurine riboside, and 5-fluorodeoxyuridine inhibited uptake of uridine competitively. Ribose and deoxyribose did not affect uridine transport, thus providing evidence for the view that the specificity of the transport mechanism resided in the purine or pyrimidine portion of the nucleoside. FREEMAN \& MONER'S (32) results supported ZEUTHEN's (119) proposal that several nucleosides, particularly uridine and deoxyuridine, interfered with mechanisms which transport thymidine into the cells.

RASMUSSEN \& ZEUTHEN's (86), HOLZ, RASMUSSEN \& ZEUTHEN's (50), and RASMUSSEN \& ZEUTHEN's $(87,88)$ studies on amino acid antagonisms have been continued by HoFFMANN, Rasmussen \& ZeUthen (42). They found that certain, but not all, amino acids interfered with the uptake of extra-cellplar Lphenylalanine, and with the exchange of intracellular L-phenylalanine with extra-cellular amino acids (Fig. 6). Before this Cirillo (16) studied uptake kinetics of arabinose in $T$. pyriformis. Arabinose is a pentose which is not metabolized by these cells. Within the con- centration range studied, he found that this sugar was not concentrated by the cells. The further addition of glucose to a culture equilibrated with arabinose resulted in a loss of arabinose from the cells against a concentration gradient. Thus he found exchange of intracellular arabinose with extra-cellular glucose. According to WILBRANDT \& ROSENBERG (111) exchange kinetics, such as those observed with the amino acids and monosaccharides, can be explained by the assumption of the existence of binding sites which can transport compounds both into and out of the cells. Such demonstrations of exchange kinetics call for specific, binding sites on the plasma membrane, rather than for vesicle-bound transport.

These results (i)-(iv) considered together suggest that the plasma membrane of $T$. pyriformis possesses carrier-mediated uptake mechanisms. Such mechanisms are well-known from bacteria and higher cells (see e.g. CHRISTENSEN (15)). Experimental evidence for them is available, however, only in the case of few of the required nutrients. It is likely that this type of uptake plays an important role, both in food-vacuole-less NPI mutant cells and in wild-type cells of $T$. pyriformis suspended in nutrient medium containing amino acids, nucleosides, vitamins and other compounds which can be utilized by the cells without prior digestion.

NILSSON (63) proposed that mucus - ultimately to be seen in the buccal cavity and in the food vacuole might concentrate nutrients prior to its appearance in the food vacuole in analogy with what CHAPMANANDRESEN \& HOLTER (12) observed in studies on the relation between the glycocalyx coat and pinocytosis in amoebae. Single nutrients or many may be involved. However, if such a concentration mechanism is to play a significant role in general food uptake in $T$. pyriformis it must operate with a wide variety of compounds required by the cells: at least 10 essential amino acids, 2 essential nucleosides, 7 vitamins, and with a number of inorganic ions (KIDDER \& DEWEY (52)). Furthermore, the adsorption must show stereospecificity in relation to at least two amino acids: HOFFMANN \& RASMUSSEN (41) showed that the initial uptake rate of D-methionine was about 11 per cent of the uptake rate of L-methionine at the same concentration, and LING \& ORIAS (54) showed that the initial uptake rate of D-phenylalanine was less than 20 


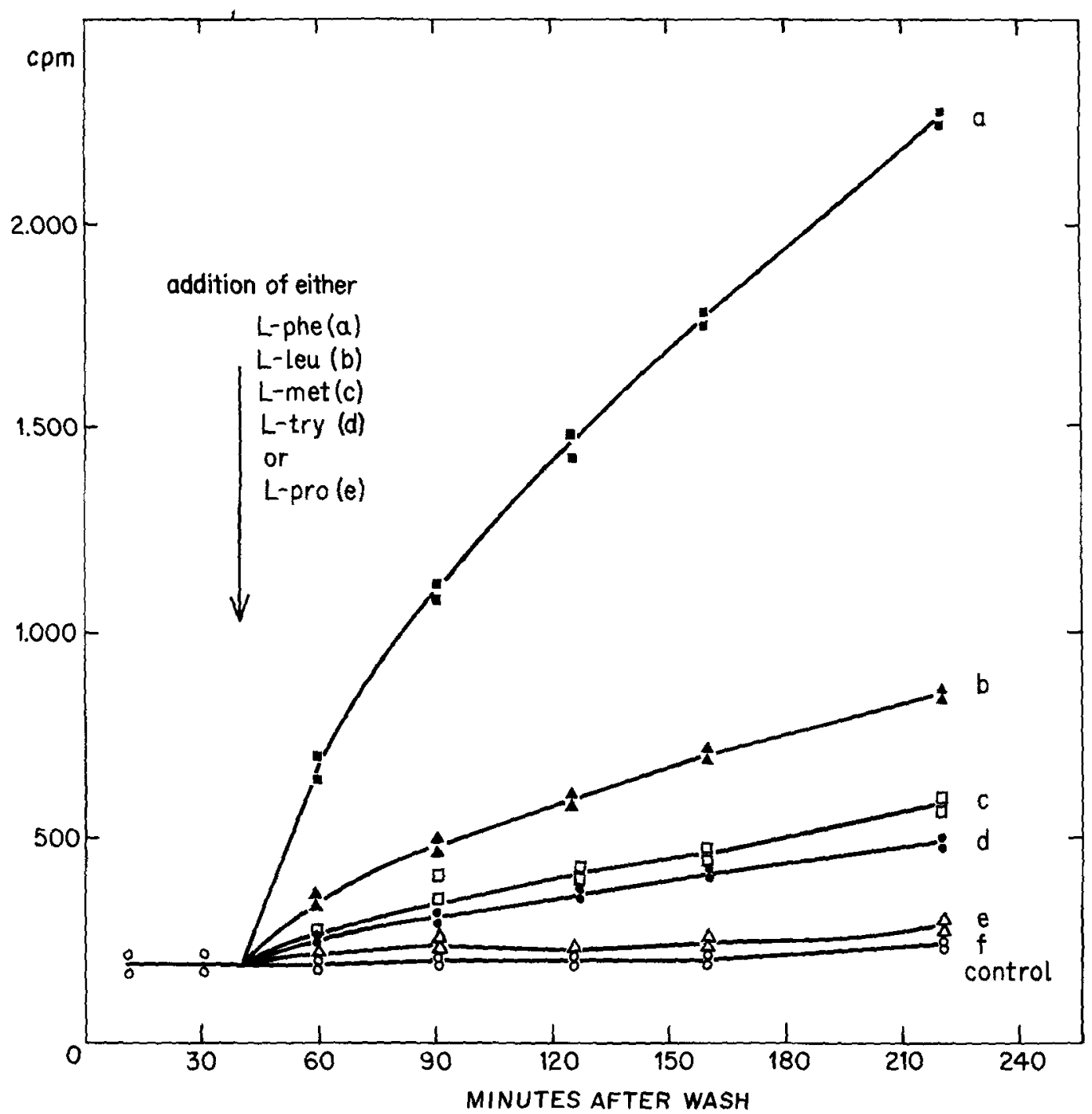

Figure 6. The effect of various amino acids (added singly to different subcultures at the point indicated by the arrow) on the radioactivity of the extra-cellular fluid of a culture in which the cells had been pre-incubated with $C^{\prime 4}$-L-phenylalanine for one hour and then transferred by three washings into fresh, non-radioactive inorganic medium (at time zero). Curve $f$ shows the level of extra-cellular radioactivity if no amino acid is added. Reproduced from ref. 42 with permission from the Danish Science Press.

per cent of that of $L$-phenylalanine. In view of this the present author would prefer to suggest that specific, rather than general adsorption mechanisms function in nutrient uptake in T. pyriformis.

\section{CONCLUDING REMARKS}

It has been shown that both the plasma membrane and the food vacuoles are active in food uptake in T. pyriformis. Separately, each of them seems able to supply at least the major part of the cell's nutrients under different sets of conditions. In most cases, however, both organelles most likely contribute to nutrient uptake at the same time.

Even though WeIDENBACH \& THOMPSON (109) found differences in the lipid composition of the plasma and vacuolar membranes, it is possible that these membranes are similar with respect to transport abilities. If we accept this idea for the moment, then it follows that lowmolecular weight compounds like amino acids 
and glucose pass both membranes equally well, whereas macromolecules would not be expected to pass any of them at a fast rate. Similarly, insoluble or complex-bound heavy metal salts would be expected not to be taken up by any of the two routes or to be taken up poorly. According to such views the food vacuoles might serve to bring nutrients into a chemical form which can pass the food-vacuolar membrane. Digestive enzymes hydrolyse organic macromolecules, and possible changes in the vacuolar acidity might bring otherwise insoluble salts or their complexes in solution. This is a broad formulation of the generally accepted view of the function of the food vacuole.

If contrary to what was suggested above the transport abilities of the plasma membrane and the food vacuole membrane are different, then the latter membrane would appear to be more permeable to iron and copper compounds than the former. This might reflect the demonstrated difference in composition of the two types of membranes, or it might reflect that addition of lysosomal membrane - in the process of fusion of lysosomes with food vacuoles - endows the food vacuole membrane with new specifications.

Because the plasma membrane is equipped with chemical pumps, the cells can grow on a balanced diet of low-molecular weight compounds, represented by the chemically defined medium. Because of the cell's ability to create changes in the micro-environment in the food vacuole the cell can feed on bacteria, organic particles and macromolecules. This dual capacity for uptake makes it possible for $T$. pyriformis to grow and multiply in a variety of media, ranging from suspensions of bacteria to chemically defined solutions with exclusively low-molecular weight solutes like amino acids, glucose, vitamins etc.

There is no doubt that $T$. pyriformis in nature in lakes etc. - feeds on micro-organisms smaller than itself, such as bacteria and diatoms, and laboratory experiments have shown that a single species of bacteria can serve as the sole food source (CURDS \& COCKBURN (21)). On the other hand, laboratory experiments have also shown that $T$. pyriformis can feed exclusively on dissolved low-molecular compounds. Presently it seems possible that natural habitats offer both particulate and dissolved food. This prompts the question: Are dissolved compounds like amino acids, vitamins and carbohydrates taken up through the cell surface at rates which contribute significantly to the cells' need? In the few cases where Km-values (half-saturation concentrations) have been determined, they seem to be fairly low. For strain GL-cells we have the following values (in $\mu \mathrm{M}$ concentrations): for L-phenylalanine 15 (STEPHENS \& KeRR (102)) and 94 (HOFFMANN \& RASMUSSEN (41)); for L-methionine 7.8 (HOFFMANN \& RASMUSSEN (41)); for uridine 2.3 (MONER, personal communication) and 2 (WOLFE (117)). For syngen 1 cells LING \& ORIAS (personal communication) found two uptake systems for L-phenylalanine: system 1 is half saturated at $20 \mu \mathrm{M}$ (same for NPI in the food-vacuole-less state) and system 2 at a concentration of about $5 \mu \mathrm{M}$ in both cell types. These concentrations were not influenced by induction of new food vacuoles. These values will now be compared with those determined for amino acid uptake in bacteria. PIPERNo \& OXENDER (73) found $\mathrm{Km}$-values of 1.1, 1.2 and $8 \mu \mathrm{M}$ for L-leucine, L-isoleucine and L-valine, respectively, in Escherichia coli; in Streptococcus faecalis MORA \& SNELL (58) found values of 80 to 100 and $50 \mu \mathrm{M}$ for glycine and L-alanine, respectively; and in Comamonas sp. GUROFF \& BROMWELL (37) found 20 and $60 \mu \mathrm{M}$ for Lphenylalanine and L-tyrosine, respectively. Thus Km-values which relate to uptake of amino acids seem to be of the same order of magnitude in bacteria and in T. pyriformis.

The natural habitat of $T$. pyriformis is abundant in bacteria, micro-organisms and detritus particles. The results presented here show that this cell is well equipped for a dual uptake of nutrients: by means of the food vacuoles it may collect and digest bacteria and micro-organisms, and by means of uptake mechanisms in the plasma membrane it may compete with the micro-organisms for dissolved low-molecular weight nutrients.

\section{SUMMARY}

Quantitative aspects of food uptake in the ciliate protozoon, Tetrahymena pyriformis, 
represent a series of unsolved problems. The cells form food vacuoles which are readily seen at low magnification in the light microscope. The view has been held that the major part of the nutrients are taken up by the food vacuoles. The first observation to contradict this view was published more than 50 years ago, but it seems to have been forgotten. To-day, many cases have been reported where the food vacuoles seem to be insufficient to cover the cells' actual uptake. Therefore uptake mechanisms and their roles in food uptake in T. pyriformis under various growth conditions were discussed. This subject was introduced in the first section.

Section 2 reviews morphological studies pertaining to structures which may take part in nutrient uptake: food vacuoles, other vesicles and the cell surface. The best known of these structures are the food vacuoles: features of their development from formation to expulsion are described; lysosomes which contain hydrolytic enzymes fuse with the food vacuoles and bring about digestion of macromolecules present here; and later, unknown mechanisms take up digestion products across the food vacuole membrane. Reports of vesicles (diameter about $0.1 \mu \mathrm{m}$ ) which may take part in food uptake are mentioned. So far, it is not known how many types of these vesicles exist in $T$. pyriformis and how rapidly they are formed.

Section 3 deals with the roles of food vacuoles, other vesicles and the cell surface in nutrient uptake. The conclusions on the role of the food vacuole build on experiments in which the multiplication rates of the celis are determined under conditions where food vacuole formation is controlled. The major part of the experiments were carried out on a mutant unable to form food vacuoles at $37^{\circ} \mathrm{C}$, but wild-type cells have been used, in which food vacuole formation was regulated by manipulations with the physical and chemical characters of the growth medium. Food vacuoles are required for rapid and sustained multiplication in standard growth media. These include solutions of unknown chemical composition (proteose peptone media) and chemically defined substrates consisting exclusively of low-molecular weight compounds like amino acids, glucose, vitamins etc. It is also shown that the cells can grow in specially supplemented media without forming food vacuoles, provided the concentrations of specific nutrients, different for different strains of $T$. pyriformis, are increased very much. The significance of the food vacuoles thus depends on the composition of the nutrient medium. The role of other vesicles in nutrient uptake is not known. The significance of the cell surface is exemplified by measurements of uptake rates of some amino acids and monosaccharides. It is likely that uptake by the cell surface plays an important role for T. pyriformis, whenever it is suspended in nutrient media which contain compounds which can be taken up without prior digestion.

Section 4 presents some ecological considerations. The few $\mathrm{Km}$-values (half-saturation values) known for uptake of amino acids in $T$. pyriformis are compared with similar values for amino acid uptake in bacteria. Since the values seem to be in the same low concentration range ( 1 to $100 \mu \mathrm{M}$ ), it is proposed that although the ciliate in its natural habitats feeds mainly on bacteria, other micro-organisms and detritus taken up by means of the food vacuoles, it is possible that under these conditions it can also compete effectively with other micro-organisms for dissolved, low-molecular weight organic nutrients.

\section{ACKNOWLEDGEMENTS}

It gives me much pleasure to thank everybody who in some way has helped towards the completion of the work reported here. First and foremost I thank Professor, dr. phil. E. ZEUTHEN, head of the Biological Institute of the Carlsberg Foundation, for inspiring collaboration and innumerable discussions over many years. Then I express sincere gratitude to my co-authors, cand. scient. T. A. KLUDT, cand. scient. E. K. HoffmanN, cand. med. vet. L. Modeweg-Hansen, Dr. H. E. Buhse, JR. and Dr. E. ORIAS for their contributions to the project. I am grateful also to dr. phil. C. CHAPMANANDRESEN, dr. phil. J. R. Nilsson and Professor G. G. HOLZ, JR. for discussions on nutrient uptake. I wish to thank Drs. G. A. Thompson, R. D. Allen and J. G. Moner for access to unpublished material. 
Furthermore I am pleased to be able to acknowledge the excellent technical assistance of Miss D. MøENBo and Mrs. B. DOHN, the competent secretarial help of Mrs. K. ANDERSEN in the preparation of the manuscript, and the unfailing co-operation of Mr. G. KNUDSEN in solving practical problems in the workshop. Mr. J. S. WATSON and Dr. R. E. PEARLMan kindly read the manuscript and I am grateful to them for their comments.

\section{REFERENCES}

1. AlleN, R. D.: Fine structure, reconstruction and possible functions of components of the cortex of Tetrahymena pyriformis. J. Protozool. 14: 553-565 (1967)

2. AlLEN, R. D.: Food vacuole membrane growth with microtubule-associated membrane transport in Paramecium. J. Cell Biol. 63: $904-922$ (1974)

3. BERGER, J. D.: Kinetics of incorporation of DNA precursors from ingested bacteria into macromolecular DNA of Paramecia aurelia. J. Protozool. 18: 419-429(1971)

4. Blum, J. J. \& T. L. Rothstein: Lysosomes in Tetrahymena. In: J. T. Dingle and R. T. Dean, eds., Lysosomes in Biology and Pathology 4, pp. 33-45. North-Holland Publishing Company (Amsterdam and New York) 1975.

5. Brandt, P. W. \& K. B. Hendil: Plasma membrane permeability and pinocytosis in Chaos chaos. Compt. Rend. Trav. Lab. Carlsberg 38: 423-443 (1972)

6. Chapman-Andresen, C.: Studies on pinocytosis in amoebae. Compt. Rend. Trav. Lab. Carlsberg 33: 73-264 (1962)

7. Chapman-Andresen, C.: Measurement of material uptake by cells: pinocytosis. In: D. M. Prescott, ed., Methods in Cell Physiology 1: pp. 277-304. Academic Press (New York and London) 1964.

8. Chapman-Andresen, C.: Biology of the large amoebae. Ann. Rev. Microbiol. 25: 27-48 (1971)

9. Chapman-ANDresen, C.: Endocytic processes. In: K. W. Jeon, ed., The Biology of Amoeba, pp. 319-348. Academic Press (New York and London) 1971.

10. Chapman-Andresen, C. \& S. Christensen: Pinocytic uptake of ferritin by the amoeba Chaos chaos measured by atomic absorption of iron. Compt. Rend. Trav. Lab, Carlsberg 38: 1958 (1970)

11. Chapman-Andresen, C. \& H. Holter: Studies on the ingestion of ${ }^{14} \mathrm{C}$-glucose by pinocytosis in the amoeba Chaos chaos. Exptl. Cell Res. suppl. 3: $52-63$ (1955)
12. Chapman-Andresen, C. \& H. Holter Differential uptake of protein and glucose by pinocytosis in Amoeba proteus. Compt. Rend. Trav. Lab. Carlsberg 34: 211-226 (1964)

13. Chapman-Andresen, C. \& J. R. Nilsson: On vacuole formation in Tetrahymena pyriformis GL. Compt. Rend. Trav. Lab. Carlsberg 36: 405 432 (1968)

14. Chapman-Andresen, C. \& D. M. Prescott: Studies on pinocytosis in the amoebae Chaos chaos and Amoeba proteus. Compt. Rend. Trav. Lab. Carlsberg 30: 57-78 (1956)

15. Christensen, H. N.: Biological Transport, 2nd edit. W. A. Benjamin Inc. (Reading, Mass.) 1975.

16. Cirillo, V. P.: Mechanism of arabinose transport in Tetrahymena pyriformis. J. Bact. 84: 754-758 (1962)

17. Conner, R. L.: Transport phenomena in protozoa. In: G. W. Kidder, ed., Chemical Zoology 1: pp. 309-350. Academic Press (New York and London) 1967.

18. Corliss; J. O.: An illustrated key to the higher groups of the ciliated protozoa, with definitions of terms. J. Protozool. 6: 265-281 (1959)

19. Cox, F. E. G.: A quantitative method for measuring the uptake of carbon particles by Tetrahymena pyriformis. Trans. Am. Microsc. Soc. 86: 261-267 (1967)

20. Crockett, R. L., P. B. Dunham \& L. RASMUSSEN: Protein metabolism in Tetrahymena pyriformis cells dividing synchronously under starvation conditions. Compt. Rend. Trav. Lab. Carlsberg 34: 451-486 (1965)

21. Curds, C. R. \& A. Cockburn: Continuous monoxenic culture of Tetrahymena pyriformis. J. Gen. Microbiol. 66: 95-108 (1971)

22. Dickie, N. \& I. E. Liener: A study of the proteolytic system of Tetrahymena pyriformis $\mathrm{W}$. I. Purification and partial characterization of the constituent proteinases. Biochim. Biophys. Acta 64: 41-51 (1962)

23. Dickie, N. \& 1. E. Liener: A study of the proteolytic system of Tetrahymena pyriformis W. II. Substrate specificity of the constituent proteinases. Biochim. Biophys. Acta 64: 52-59 (1962)

24. Dunham, P. B. \& D. L. KRopp: Regulation of solutes and water in Tetrahymena. In: A. M. Elliott, ed., Biology of Tetrahymena pp. 165198. Dowden, Hutchinson and Ross, Inc. (Stroudsburg, Pa.) 1973.

25. de Duve, C: From cytases to lysosomes. Fed Proc. 23: 1045-1049 (1964)

26. Elliott A. M.: Primary lysosomes in Tetrahymena pyriformis. Science 149: 640-641 (1965)

27. ElLlotT, A. M., ed., Biology of Tetrahymena. Dowden, Hutchinson \& Ross, Inc. (Stroudsburg, Pa.) 1973.

28. Elliott, A. M. \& G. L. Clemmons: An ul- 
trastructural study of ingestion and digestion in Tetrahymena pyriformis. J. Protozool. 13: 311-323 (1966)

29. Elliott, A. M. \& J. R. KenNedy: Morphology of Tetrahymena. In: A. M. Elliott, ed., Biology of Tetrahymena, pp. 57-87. Dowden, Hutchinson \& Ross, Inc. (Stroudsburg, Pa.) 1973.

30. Forer, A., J. R. Nilsson \& E. Zeuthen: Studies on the oral apparatus of Tetrahymena pyriformis GL. Compt. Rend. Trav. Lab. Carlsberg 38: 67$86(1970)$

31. Freeman, M. \& J. G. Moner: Uridine transport in Tetrahymena. In: P. de Puytorac and J. Grain, eds., Progress in Protozoology, p. 144. Université de Clermont (1973)

32. Freeman, M. \& J. G. Moner: The effects of deoxyribonucleoside analogues on uridine transport in Tetrahymena pyriformis GL. J. Protozool. 21: 433 (1974)

33. Friend, D. S.\& M. G. Farquhar: Functions of coated vesicles during protein absorption in the rat vas deferens. J. Cell Biol. 35: 357-376 (1967)

34. Furgason, W. H.: The significant cytostomal pattern of the "Glaucoma-Colpidium group", and the proposed new genus and species, Tetrahymena geleii. Arch. Protistenk. 94: 224-266 (1940)

35. Gavin, R. H.: The oral apparatus of Tetrahymena pyriformis, mat. type 1, var. 1. Exptl. Cell Res. 85: 212-216 (1974)

36. Grell, K. G.: Protozoology. Springer-Verlag (Berlin, Heidelberg, New York) 1973.

37. Guroff, G. \& K. E. Bromwell: Phenylalanine uptake and phenylalanine-binding material in Comamonas sp. Arch. Biochem. Biophys. 137: 379-387 (1970)

38. Hamburger, K. \& E. Zeuthen: Synchronous divisions in Tetrahymena pyriformis as studied in an inorganic medium. Exptl. Cell Res. 13: 443453 (1957)

39. HeNDIL, K. B.: Ion exchange properties of the glycocalyx of the amoeba Chaos chaos and its relation to pinocytosis. Compt. Rend. Trav. Lab. Carlsberg 38: 187-211 (1971)

40. HiLl, D. L.: The Biochemistry and Physiology of Tetrahymena. Academic Press (New York and London) 1972.

41. HoffmanN, E. K. \& L. Rasmussen: Phenylalanine and methionine transport in Tetrahymena pyriformis: Characteristics of a concentrating, inducible transport system. Biochim. Biophys. Acta 226: 206-216 (1972)

42. Hoffmann, E. K., L. Rasmussen \& E. Zeuthen: Evidence for a common transport system for a group of amino acids in Tetrahymena. Compt. Rend. Trav. Lab. Carlsberg 38: 133-143 (1970)

43. Hofrmann, E. K., L. Rasmussen\& E. Zeuthen: Cytochalasin B: Aspects of phagocytosis in nutrient uptake in Tetrahymena. J. Cell Sci. 15: 403-406 (1974)
44. Holter, H.: Pinocytosis. Intern. Rev. Cytol. 8: 481-504 (1959)

45. Holter, H.: Problems of pinocytosis, with special regard to amoebae. Ann. N. Y. Acad. Sci. 78: 524-537 (1959)

46. Holter, H.: Pinocytosis. In: J. L. Morgan and A. V. S. de Réuck, eds., Ciba Foundation Symposium on Enzymes and Drug Action pp. 30-39. J. \& A. Churchill Ltd. (London) 1962.

47. Holter, H. \& J. M. Marshall: Studies on pinocytosis in the amoeba Chaos chaos. Compt. Rend. Trav. Lab. Carlsberg. Ser. chim. 29: 7-27 (1954)

48. Holz, JR., G. G.,: The nutrition of Tetrahymena: Essential nutrients, feeding and digestion. In: A. M. Elliott, ed., Biology of Tetrahymena pp. 89-98. Dowden, Hutchinson \& Ross, Inc. (Stroudsburg, Pa.) 1973.

49. Holz, JR., G. G., J. Erwin, N. Rosenbaum \& S. AARONSON: Triparanol inhibition of Tetrahymena and its prevention by lipids. Arch. Biochem. Biophys. 98: 312-322 (1962)

50. Holz, JR., G. G., L. Rasmussen \& E. Zeuthen: Normal versus synchronized division in Tetrahymena pyriformis. A study with antimetabolites. Compt. Rend. Trav. Lab. Carlsberg 33: 289-300 (1963)

51. Hutner, S. H., H. Baker, O. Frank \& D. Cox: Nutrition and metabolism in protozoa. In: R. N. Fiennes, ed., Biology of Nutrition 18, pp. 85-177. Pergamon Press (Oxford and London) 1972.

52. Kidder, G. W. \& V. C. Dewey: The biochemistry of ciliates in pure culture. In: A. Lwoff, ed., Biochemistry and Physiology of Protozoa 1, pp. 323-400. Academic Press (New York) 1951.

53. Kitchings, J. A.: Food vacuoles. Protoplasmatologia 3 Chapter D 3b, pp. 1-54. Springer-Verlag (Vienna) 1956.

54. LiNG, K.-Y. \& E. ORIAS: Two carrier-mediated systems for L-phenylalanine transport in wild type Tetrahymena and in a conditional phagocytotic-less mutant. J. Cell Biol. 63: 196a. (1974)

55. Lwoff, A.: Sur la nutrition des Infusoires. Compt. Rend. Hebd. Seance Acad. Sci. (Paris), D 176: 928-930(1923)

56. LwoFf, A: From protozoa to bacteria and viruses. Fifty years with microbes. Ann. Rev. Microbiol. 25: 1-26 (1971)

57. Mast, S. O.: The food vacuole in Paramecium. Biol. Bull. 93: 31-72 (1947)

58. Mora, J. \& E. E. SNell: The uptake of amino acids by cells and protoplasts of $S$. faecalis. Biochemistry 2: 136-141 (1963)

59. MULLER, M.: Secretion of acid hydrolases and its intracellular source in Tetrahymena pyriformis. J. Cell Biol. 52: 478-487 (1972)

60. Múller, M., P. Baudhuin \& C. de Duve: Lysosomes in Tetrahymena pyriformis. I. Some 
properties and lysosomal localization of acid hydrolases. J. Cell Physiol. 68: 165-176 (1966)

61. Múller, M. \& P. Röhlich: Studies on feeding and digestion in protozoa. II. Food vacuole cycle in Tetrahymena corlissi. Acta Microbiol. Acad. Sci. Hung. 10: 297-305 (1961)

62. Nilsson, J. R.: Cytolysomes in Tetrahymena pyriformis GL. I. Synchronized cells dividing in inorganic salt medium. Compt. Rend. Trav. Lab. Carlsberg 38: 87-106 (1970)

63. Nilsson, J. R.: Further studies on vacuole formation in Tetrahymena pyriformis. Compt. Rend. Trav. Lab. Carlsberg 39: 83-110 (1972)

64. Nilsson, J. R.: Physiological and structural studjes on Tetrahymena pyriformis GL. Compt. Rend. Trav. Lab. Carlsberg 40: 21 5-355 (1976)

65. Nilsson, J. R. \& O. BeHNKE: Studies on a surface coat of Tetrahymena. J. Ultrastruct. Res. 36: $542-544$ (1971)

66. Nilsson, J. R., T. R. Ricketts \& E. Zeuthen: Effects of cytochalasin $B$ on cell division and vacuole formation in Tetrahymena pyriformis GL. Exptl. Cell Res. 79: 456-459 (1973)

67. Nilsson, J. R. \& N. E. Williams: An electron microscope study of the oral apparatus of Tetrahymena pyriformis. Compt. Rend. Trav. Lab. Carlsberg 35: 119-141 (1966)

68. Orias, E., I. Charvat, K.-Y. Ling \& N. A. Pollock: A Tetrahymena mutant with heat sensitive phagocytosis. J. Cell Biol. 59: 245a (1973)

69. ORIAS, E. \& N. A. Pollock: Temperature-sensitive phagocytosis in a Tetrahymena mutant. In: P.de Puytorac and J. Grain, eds., Progress in Protozoology, p. 468. Université de Clermont (1973)

70. ORIAS, E. \& N. A. POLlOCK: Heat-sensitive development of the phagocytotic organelle in a Tetrahymena mutant. Exptl. Cell Res. 90: 345357 (1975)

71. Orias, E. \& L. Rasmussen: Dual capacity for nutrient uptake in Tetrahymena. II. Role of the two systems in vitamin uptake. In preparation.

72. ORIAS, E. \& L. RASMUSSEN: Dual capacity for nutrient uptake in Tetrahymena. IV. Growth without vacuoles and its implications. Exptl. Cell Res. (1976)

73. Piperno, J. R. \& D. L. Oxender: Amino acidbinding protein released from Escherichia coli by osmotic shocks. J. Biol. Chem. 241: 5732-5734 (1966)

74. Pitelka, D. R.: Fine structure of the silver-line and fibrillar systems of three tetrahymenid ciliates. J. Protozool. 8: 75-89 (1961)

75. PitelkA, D. R.: Electron-Microscopic Structure of Protozoa. Pergamon Press (Oxford) 1963.

76. Plesner, P., L. Rasmussen \& E. Zeuthen: Techniques used in the study of synchronous Tetrahymena. In E. Zeuthen, ed., Synchrony in Cell Division and Growth, pp. 543-563. John Wiley (New York)1964.
77. Pruett, P. O., R. L. Conner \& J. R. Pruett: Orthophosphate flux across the membrane of Tetrahymena pyriformis W. J. Cell Physiol. 70: 217-224 (1967)

78. Rannestad, J. \& N. E. Williams: The synthesis of microtubule and other proteins of the oral apparatus in Tetrahymena pyriformis. J. Cell Biol. 50:709-720 (1971)

79. Rasmussen, L:: On the role of food vacuole formation in the uptake of dissolved nutrients by Tetrahymena. Exptl. Cell Res. 82: 192-196 (1973)

80. RASMUSSEN, L.: Food vacuole membrane in nutrient uptake by Tetrahymena. Nature 250 : 157-158 (1974)

81. Rasmussen, L., H. E. Buhse, JR. \& K. Groh: Efficiency of filter-feeding in two species of Tetrahymena. J. Protozool. 22: 110-111 (1975)

82. Rasmussen, L. \& T. A. Kuvdt: Particulate material as a prerequisite for rapid cell multiplication in Tetrahymena cultures. Exptl. Cell Res. 59: 457-463 (1970)

83. Rasmussen, L. \& L. Modeweg-Hansen: Cell multiplication in Tetrahymena cultures after addition of particulate material. J. Cell Sci. 12: 275-286 (1973)

84. Rasmussen, L. \& E. ORIAS: Tetrahymena: Growth without phagocytosis. Science 190:464465 (1975)

85. Rasmussen, L. \& E. Orias: Dual capacity for nutrient uptake in Tetrahymena. Importance of the oral uptake system for $\mathrm{Fe}$ and $\mathrm{Cu}$ uptake. Carlsberg Res. Comm, 41: 81-90 (1976)

86. Rasmussen, L. \& E. Zeuthen: Cell division and protein synthesis in Tetrahymena, as studied with p-fluorophenylalanine. Compt. Rend. Trav. Lab. Carlsberg 32: 333-358 (1962)

87. Rasmussen, L. \& E. Zeuthen: Cell division in Tetrahymena adapting to p-DL-fluorophenylalanine. Exptl. Cell Res. 41: 462-465 (1966)

88. Rasmussen, L. \& E. Zeuthen: Amino acid antagonisms in Tetrahymena. Compt. Rend. Trav. Lab. Carlsberg 35: 85-100 (1966)

89. RICKETTS, T. R.: Effect of endocytosis upon acid phosphatase activity of Tetrahymena pyriformis. Protoplasma 71: 127-137 (1970)

90. RickeTtS, T. R.: Endocytosis in Tetrahymena pyriformis. Selectivity of uptake of particles and the adaptive increase in cellular acid phosphatase activity. Exptl. Cell Res. 66: 49-58 (1971)

91. Ricketts, T. R.: Periodicity of endocytosis in Tetrahymena pyriformis. Protoplasma 73: 387-396 (1971)

92. RicketTs, T. R.: The induction of endocytosis in starved Tetrahymena pyriformis. J. Protozool. 19: 372-374 (1972)

93. Rothstein, T. L. \& J. J. Blum: Lysosomal physiology in Tetrahymena. III. Pharmacological studies on acid hydrolase release and the inges- 


\section{RASMUSSEN: Nutrient uptake in Tetrahymena}

tion and egestion of dimethylbenzanthracene particles. J. Cell Biol. 62: 844-859 (1974)

94. Rothstein, T. L. \& J. J. BuUM: Lysosomal physiology in Tetrahymena. IV. Effect of dichloroisoproterenol on the intracellular source of released acid hydrolases. Exptl. Cell Res. 87: 168-174 (1974)

95. SATIR, B.: The final steps in secretion. Scientific American 233: 29-37 (1975)

96. SatiR, B., C. Schooley \& P. SAtiR: Membrane fusion in a model system: mucocyst secretion in Tetrahymena. J. Cell Biol. 56: 153-176 (1973)

97. SATTLER, C:: Membrane specializations in Tetrahymena pyriformis: an ultrastructural study of the pellicle and ciliary membranes of the somatic and oral regions including a reconstruction of the buccal cavity. Ph. D. thesis, University of Colorado (1974)

98. Seaman, G. R.: Metabolism of free-living ciliates. In: S. H. Hutner and A. Lwoff, eds., Biochemistry and Physiology of Protozoa 2, pp. 91-158. Academic Press (New York) 1955.

99. Seaman, G. R.: Some aspects of phagotrophy in Tetrahymena. J. Protozool. 8: 204-212 (1961)

100. Scherbaum, O. \& E. Zeuthen: Induction of synchronous cell division in mass cultures of Tetrahymena pyriformis. Exptl. Cell Res. 6: 221227 (1954)

101. Sмith, I. B. Cited by Blum \& Rothstein in ref. 4.

102. Stephens, G. C. \& N. S. KerR: Uptake of phenylalanine by Tetrahymena pyriformis. Nature 194: 1094-1095 (1962)

103. Stossel, T. P., R. J. Mason \& M. Vaughan: Quantitative studies of phagocytosis by polymorphonuclear leukocytes. Use of emulsions to measure the initial rate of phagocytosis. J. Clin. Invest. 51: 615-622 (1972)

104. Thormar, H.: Delayed division in Tetrahymena pyriformis induced by temperature changes. Compt. Rend. Trav. Lab. Carlsberg 31: 207-225 (1959)

105. Tokuyasu, K. \& O. H. Scherbaum: Ultrastructure of mucocysts and pellicle of Tetrahymena pyriformis. J. Cell Biol. 27: 67-81 (1965)

106. Ulsamer, A. G., F. R. Smith \& E. D. Korn: Lipids of Acanthamoeba castellanii. Composition and effects of phagocytosis on incorporation of radioactive precursors. J. Cell Biol. 43: 105-114 (1969)

107. Ulsamer, A. G., P. L. WRight, M. G. WETZEL \& E. D. KorN: Plasma and phagosome membranes of Acanthamoeba castellanii. J. Cell Biol. 51: 193-215 (1971)

108. Viswanatha, T. \& I. E. Liener: Utilization of native and denatured proteins by Tetrahymena pyriformis W. Arch. Biochem. Biophys. 56: 222229 (1956)

109. Weidenbach, A. L. S. \& G. A. Thompson, JR.: Studies of membrane formation in Tetrahymena pyriformis. VIII. On the origin of membranes surrounding food vacuoles. J. Protozool. 21; 745-750 (1974)

110. Wichterman, R.: The Biology of Paramecium. The Blackiston Co. Inc. (New York and Toronto) 1953.

111. Wilbrandt, W. \& T. Rosenberg: The concept of carrier transport and its corrolaries in pharmacology. Pharmacol. Rev, 13: 109-183 (1961)

112. Williams, N. E. \& J. H. Luft: Use of a nitrogen mustard derivative in fixation for electron microscopy and observations on the ultrastructure of Tetrahymena. J. Ultrastructure Res. 25: 271-292 (1968)

113. Williams, N. E., O. Michelsen \& E. Zeuthen: Synthesis of cortical proteins in Tetrahymena. $\mathbf{J}$. Cell Sci. 5: 143-162 (1969)

114. Williams, N. E. \& E. M. Nelson: Regulation of microtubules in Tetrahymena. II. Relation between turnover of microtubule proteins and microtubule dissociation and assembly during oral replacement. J. Cell Biol. 56: 458-465 (1973)

115. Williams, N. E. \& E. Zeuthen: The development of oral fibers in relation to oral morphogenesis and induced division synchrony in Tetrahymena. Compt. Rend. Trav. Lab. Carlsberg 35: 101-118 (1966)

116. WOLF, R. \& R. D. Allen: The cytoproct of Tetrahymena pyriformis: microtubules, food vacuole membrane and endocytosis. J. Protozool. 21: (suppl.) 425 (1974)

117. WOLFE, J.: Structural analysis of basal bodies of the isolated oral apparatus of Tetrahymena pyriformis. J. Cell Sci. 6: 679-700 (1970)

118. WolfE, J.: Uridine uptake in a unicellular eukaryote during the interdivision period and after growth arrest. J. Cell Physiol. 85: 73-86 (1975)

119. ZeUTHEN, E.: Thymine starvation by inhibition of uptake and synthesis of thymine compounds in Tetrahymena. Exptl. Cell Res. 50: 37-46 (1968)

The literature study for the present review was completed in November 1975. Since then an important report which includes new information and new discussions on endocytosis in Tetrahymena pyriformis has appeared (NILSSON (64)). It has not been possible to incorporate and discuss this report here, but the reader is strongly advised to refer to it. 